\title{
The Precambrian Khondalite Belt in the Daqingshan area, North China Craton: evidence for multiple metamorphic events in the Palaeoproterozoic
}

\author{
Yusheng Wan ${ }^{1,2}$, Dunyi Liu ${ }^{1,2}$, Chunyan Dong ${ }^{1,2}$, Zhongyuan $\mathrm{Xu}^{3}$, Zhejiu Wang ${ }^{4}$, Simon A Wilde ${ }^{5}$, \\ Zhenghong Liu ${ }^{3}$, Zhensheng Yang ${ }^{3}$, Hongying Zhou ${ }^{1,2}$ \\ ${ }^{1}$ Institute of Geology, Chinese Academy of Geological Sciences, Beijing, 100037, China \\ (e-mail: wanyusheng@bjshrimp.cn) \\ ${ }^{2}$ Beijing SHRIMP Centre, Beijing, 100037, China \\ ${ }^{3}$ College of Earth Sciences, Jilin University, Changchun 130061, China \\ ${ }^{4}$ Chinese Academy of Geological Sciences, Beijing, 100037, China \\ ${ }^{5}$ Department of Applied Geology, Curtin University of Technology, Perth, Western Australia, 6845, \\ Australia
}

\begin{abstract}
High-grade pelitic metasedimentary rocks (khondalites) are widely distributed in the northwestern part of the North China Craton and were named the "Khondalite Belt". Prior to the application of zircon geochronology, a stratigraphic division of the supracrustal rocks into several groups was established using interpretative field geology. We report here SHRIMP U-Pb zircon ages and $\mathrm{Hf}$ isotope data on metamorphosed sedimentary and magmatic rocks at Daqingshan, a typical area of the Khondalite Belt. The main conclusions are as follows. 1) The early Precambrian supracrustal rocks belong to three sequences: a $2.56-2.51 \mathrm{Ga}$ supracrustal unit (the previous Sanggan "group"), a 2.51-2.45 Ga supracrustal unit (a portion of the previous upper Wulashan "group") and a 2.0-1.95 Ga supracrustal unit (including the previous lower Wulashan "group", a portion of original upper Wulashan "group" and the original Meidaizhao "group"; the units thus do not represent a true stratigraphy. 2) Strong tectonothermal events occurred during the late Neoarchaean to late Palaeoproterozoic, with four episodes recognised: $2.6-2.5 \mathrm{Ga}, 2.45-2.37 \mathrm{Ga}, 2.3-2.0 \mathrm{Ga}$ and 1.95-1.85 Ga, with the latest event being consistent with the assembly of the Palaeoproterozoic supercontinent Columbia. 3) During the late Neoarchaean to late Palaeoproterozoic (2.55-2.5 Ga, $2.37 \mathrm{Ga}$ and $2.06 \mathrm{Ga})$ juvenile, mantle-derived
\end{abstract}


material was added to the crust.

Knowledge of the assembly and break-up of Precambrian supercontinents (e.g., Bleeker, 2003) is important for understanding the early evolution of continental crust and thereby global geodynamics. Prior to the Rodinia supercontinent, there may have been a Palaeoproterozoic supercontinent, commonly referred to as "Columbia" (Rogers and Santosh, 2002; Zhao et al., 2002, 2004). However, the timing of the assembly and break-up of Columbia is still debatable. A major reason is that in many cratonic blocks where tectonothermal events relating to the assembly and break-up are well developed, detailed geochronological studies have not been carried out. This paper addresses this problem by presenting the results of an isotopic study of metasediments close to proposed Columbia suture zones in north China.

The North China Craton (NCC) is a cratonic block that contains some of the oldest rocks in the world. Major advancements in understanding the geological history of the NCC have been made in the past few years. Zhao et al. (1998, 1999, 2000, 2001, 2005) recognized two major Palaeoproterozoic collisional belts: the Khondalite Belt and Trans-North China Orogen in the western and central parts of the craton, respectively (Fig. 1). The Trans-North China Orogen divides the North China Craton into two discrete blocks, named the Eastern and Western Blocks, whereas the Palaeoproterozoic Khondalite Belt divides the Western Block into the Yinshan Terrane in the north and the Ordos Terrane in the south (Fig. 1). On the other hand, Li et al. (2002), Kusky and Li (2003) and Kusky et al. (2007) proposed collision in the Neoarchaean, with the collisional belt similar in spatial distribution to that of the Palaeoproterozoic one proposed by Zhao et al. (1998, 1999, 2000, 2001, 2005) except that the northern portion of the belt turns eastward into western Liaoning-southern Jilin provinces. These authors proposed that the Western and Eastern blocks collided and amalgamated as early as the end of the Archaean, forming the unified NCC at this time. They also identified an Inner-Mongolia-North Hebei Orogenic Belt (or more simply the North Hebei Orogenic Belt: NHOB) in the north and a Hengshan Plateau (including the Khondalite Belt) in the south along the northwest part of the NCC (Kusky and Li, 2003; Kusky et al., 2007). These authors interpreted the NHOB as probably being generated by accretion along an active continental margin at the end of Neoarchaean, whilst to the south, the NHOB was thrust over the Khondalite Belt of the NCC. There are now coherent outlines for the timing and tectonic processes involved in the Palaeoproterozoic amalgamation and extensive knowledge concerning the pre-collisional history of the Trans-North China 
Orogen (Wu and Zhong, 1998; Zhao et al., 1999, 2000, 2001, 2005, Wilde et al., 2002; Kröner et al., 2005a, 2005b, 2006). However, the evolution of the Palaeoproterozoic Khondalite Belt still remains largely unknown.

The Khondalite Belt extends in an east-west direction (Fig. 1) and is dominated by graphite-bearing sillimanite-garnet gneiss, garnet quartzite, felsic paragneiss, calc-silicate rock and marble, which have previously been referred to informally as the "khondalite series" in the Chinese literature (following the Indian usage) and were considered to represent stable continental margin deposits and to be Archaean in age, mainly based on their high metamorphic grade (Shen et al., 1990; Lu et al., 1996; Hu et al., 1994; Yang et al., 2000). Qian \& Li (1999) suggested that the khondalites were deposited unconformably on TTG rocks, both of Archaean age. However, these metasedimentary rocks contain Palaeoproterozoic detrital zircons and give younger whole-rock $\mathrm{Nd}$ isotope model ages, supporting recent field-based geological evidence for a post-Archaean age (Wu et al., 1997, 1998; Wan et al., 2000a, 2000b; Xia et al., 2006a, 2006b; Dong et al., 2007), The latter interpretation supports the view of Zhao et al. (2005) that the Western Block of the NCC consists of the Yinshan Block in the north and the Ordos Block in the south, separated by the Palaeoproterozoic Khondalite Belt. Recently, Guo et al. (2006) and Santosh et al. (2006, 2007a, b) reported the important discovery in the belt of diagnostic mineral assemblages indicating extreme crustal metamorphism at ultrahigh-temperature conditions. However, it is unclear whether all the metasedimentary rocks in the Khondalite Belt formed at the same time. Furthermore, besides the metasedimentary rocks, there are many other rock types present, such as TTG gneisses, mafic granulites, charnockites, as well as I-type and S-type granitic rocks. It is also important to note that it has recently been established that some of these granitic rocks formed earlier than the khondalites (in the Palaeoproterozoic), as indicated by their emplacement ages of 2.3-2.0 Ga (Li et al., 2004; Zhong et al. 2006a, 2006b; Dong et al., 2007).

In order to further understand the evolution of the Khondalite Belt during the Palaeoproterozoic, we report SHRIMP U-Pb zircon ages and Hf isotope data on metamorphosed sedimentary and magmatic rocks in the Daqingshan area (Fig. 1). Our data show that the Palaeoproterozoic history of the Khondalite Belt is more complex than previously thought, possibly related to tectonic slices of different ages and origins being interdigitated with each other during the late Palaeoproterozoic continent-continent collision. 


\section{Geological background}

The Daqingshan area is a representative part of the Khondalite Belt in the NCC (Fig. 1). The following summary of the lithologies is largely based on Yang et al. (2003, 2004), although their age interpretations are questioned in light of the new zircon geochronology presented in this study. At Daqingshan and adjacent areas, the Precambrian metamorphic rocks have been divided into the Palaeoarchaean Sanggan (Xinghe) Group, the Mesoarchaean Wulashan Group, the Neoarchaean Seertenshan Group, the Palaeoproterozoic Meidaizhao Group and the Mesoproterozoic Zhaertai Group (Yang et al., 2004). The subdivisions are mainly based on geological field studies, with only a few conventional U-Pb zircon dates to support them. The Seertenshan and Zhaertai groups are distributed north of our study area, so they are not considered in detail here. It is important to indicate that the sequence of metamorphic rocks within these groups is unclear in many cases, so we are not necessarily dealing with a sedimentary sequence, rather a series of "complexes" whose stratigraphy remains unknown. However, we will use the term "group" in an informal way in this paper, so that readers can compare our results with the existing Chinese literature.

The Sanggan "group" occurs mainly in the southern part of the study area (Fig. 1) and has been sub-divided into a mesocratic granulite unit and a leucocratic granulite unit. The former is mainly composed of hypersthene-biotite-plagioclase gneiss, magnetite-hypersthene-plagioclase gneiss, retrogressed two-pyroxene-plagioclase gneiss (with some retrogressed hypersthene-two-feldspar granulite), hypersthene-alkali-feldspar granulite, retrogressed two-pyroxene granulite and hypersthene-magnetite quartzite. The leucocratic unit is mainly composed of pyroxene-two-feldspar gneiss, with some two-pyroxene-alkali-feldspar gneiss and amphibole-hypersthene granulite. The Sanggan "group" underwent granulite-facies metamorphism and was locally retrograded to amphibolite-facies. The protoliths of the mesocratic and leucocratic granulite units have been interpreted as basic-intermediate and intermediate-acid volcano-sedimentary rocks, respectively (Yang et al., 2004).

Fig. 1 here 
The Wulashan "group" has been sub-divided into lower and upper subgroups. The lower subgroup is mainly distributed in the northern part of the study area (Fig. 1) and is further subdivided into melanocratic gneiss and leucocratic gneiss sub-units. The former is mainly composed of quartz-bearing pyroxene amphibolite, quartz-alkali-feldspar amphibolite, amphibole-plagioclase gneiss, biotite-amphibole-two-feldspar gneiss and pyroxene-magnetite quartzite. The leucocratic gneiss is felsic in composition and mainly composed of biotite-alkali-feldspar gneiss, biotite-two-feldspar gneiss, biotite-plagioclase gneiss and amphibole-feldspar gneiss. Both sub-units underwent upper amphiboliteto granulite-facies metamorphism and have been regarded as having similar protoliths to rocks of the Sanggan "group" (Yang et al., 2004). There are some associated metamorphosed plutons in both the Sanggan "group" and lower Wulashan "subgroup", but more work is required to define their spatial distribution and size.

The upper subgroup of the Wulashan "group" is similar in rock association and metamorphism to the khondalite rock series in southern India (Chacko et al., 1992) and was named the "khondalite series" in China. It is distributed widely in the study area (Fig. 1) and has been sub-divided into three main components: garnet-biotite-quartzo-feldspathic gneiss, diopside gneiss and marble (Xu et al., 2005). The garnet-biotite gneiss sub-unit contains sillimanite-cordierite-garnet-biotite gneiss, graphite-bearing gneiss, fine-grained garnet leucogneiss, garnet quartzite and banded iron formation (BIF). The diopside gneiss sub-unit is mainly composed of feldspar-diopside gneiss, but also contains diopsidite and diopside marble. Some of the diopside marbles have been considered as crustally derived carbonate-rich magmatic rocks (Wan et al., in review). Finally, the marble sub-unit is mainly composed of dolomitic marble, with thin interlayers of diopside quartzite and tremolite-schist. These rocks underwent upper amphibolite- (to granulite-?) facies metamorphism.

Based on petrographical study and P-T calculations, Jin et al. (1991) established that the Sanggan and Wulashan "groups" had different PTt paths; showing anti-clockwise and clockwise paths, respectively. They further suggested that the Sanggan "group" was Neoarchaean and the Wulashan "group" was Palaeoproterozoic in age. The idea that the khondalite unit of the Wulashan "group" formed during the Palaeoproterozoic was also supported by the age distribution of detrital zircons (Xia et al., 2006b; Wan et al., 2006). Additionally, the Sanggan and Wulashan "groups" were extensively modified by anatexis, 
locally resulting in the formation of granites, whose chemistry is consistent with derivation from the adjacent metasedimentary rocks (e. g., Song et al., 2005).

The Meidaizhao "group" occurs southeast of the area shown in Figure 1 and consists mainly of fine-grained biotite gneiss, fine-grained quartzo-feldspathic gneiss and quartzite. The main minerals are plagioclase, K-feldspar, quartz, biotite, muscovite, chlorite and epidote, showing mineral associations typical of greenschist-facies metamorphism. It has been considered Palaeoproterozoic in age and to unconformably overlie the khondalite unit of the Wulashan "group" (Xu et al., 2003).

\section{Analytical techniques}

Zircon crystals were obtained using standard crushing and separation techniques and U-Pb dating was carried out using the SHRIMP II ion microprobe at the Beijing SHRIMP Centre, CAGS. The hand-picked crystals, together with the TEMORA standard (with a conventionally determined ${ }^{206} \mathrm{~Pb} /{ }^{238} \mathrm{U}$ age of 417 Ma - Black et al., 2003), were cast in epoxy resin discs and polished. All grains were photographed in both transmitted and reflected light and then imaged using cathodoluminescence (CL) in order to reveal the internal structure and to identify preferred locations for SHRIMP analysis. Mineral and $\mathrm{CO}_{2}$ inclusions were identified using a Jasco nitrogen Raman spectroscope with a Renishaw 1000 laser using the 514.5 $\mathrm{nm}$ line at the Institute of Geology, CAGS. Zircon dating procedures were similar to those described by Williams (1998). The intensity of the primary $\mathrm{O}^{2--}$ ion beam was $8 \mathrm{nA}$ and the spot size was $\sim 30 \mu \mathrm{m}$, with each site rastered for 120-180 s before analysis. Five scans through the 9 mass stations were made for each spot analysis. Data processing was carried out using the Squid and Isoplot programs (Ludwig, 2001a

and $\mathrm{b}$ ), and the measured ${ }^{204} \mathrm{~Pb}$ was applied for the common lead correction, assuming an isotopic composition of Broken Hill lead. The uncertainties given in the data tables and figures for individual analyses are quoted at the $1 \sigma$ level, whereas those for weighted mean ages are quoted at the $95 \%$ confidence level.

The in-situ Lu-Hf isotopic composition of zircon was measured with a Geolas-193 laser-ablation microprobe, attached to a Neptune multi-collector ICPMS at the State Key Laboratory of Lithospheric Evolution, Institute of Geology and Geophysics, Chinese Academy of Sciences in Beijing. A $193 \mathrm{~nm}$ 
UVArF excimer laser ablation system was used for laser ablation analysis. Instrumental conditions and analytical procedures are described in Wu et al. (2006). Ablation times were about $26 \mathrm{~s}$ for 200 cycles of each measurement, with a $6 \mathrm{~Hz}$ repetition rate, a laser power of $100 \mathrm{~mJ} /$ pulse and a spot size of $63 \mu \mathrm{m}$. Zircon standard $91500\left({ }^{176} \mathrm{Hf} /{ }^{177} \mathrm{Hf}=0.282306\right.$; Woodhead et al., 2004) was analyzed $(n=13)$ before and after the unknowns and yielded average ${ }^{176} \mathrm{Hf} /{ }^{177} \mathrm{Hf}_{(\mathrm{c})}$ and ${ }^{176} \mathrm{Lu} /{ }^{177} \mathrm{Hf}_{(\mathrm{c})}$ values of 0.282287 and 0.000286 , respectively. The errors for the $\mathrm{Lu}-\mathrm{Hf}$ isotope results are quoted at the $2 \sigma$ level. The calculation of $\mathrm{Hf}$ model ages was based on a depleted-mantle source with a present-day ${ }^{176} \mathrm{Hf} /{ }^{177} \mathrm{Hf}=0.28325$, using the ${ }^{176} \mathrm{Lu}$ decay constant $1.865 \times 10^{-11}$ year $^{-1}$ (Scherer et al., 2001). The calculation of $\varepsilon_{\mathrm{Hf}}(\mathrm{T})$ values was based on zircon SHRIMP U-Pb ages and the chondritic values $\left({ }^{176} \mathrm{Hf} /{ }^{177} \mathrm{Hf}=0.282772,{ }^{176} \mathrm{Lu} /{ }^{177} \mathrm{Hf}=0.0332\right.$; Blichert-Toft \& Albarède, 1997).

\section{SHRIMP dating of zircons}

In order to determine the formation ages of the main units and understand the tectonothermal histories in the Daqingshan area, a total of eight rock samples, including metamorphic rocks from the Sanggan, Wulashan and Meidaizhao "groups" and metamorphosed basic dyke and gabbro were dated using the SHRIMP U-Pb zircon dating technique. The results are presented below.

\section{Sanggan "group"}

A two-pyroxene-bearing retrogressed granulite (sample NM0403) was collected from the mesocratic granulite unit of the Sanggan "group" northeast of Hademengou (N4041'55", E109 41'52") (Fig. 1). It comes from an homogenous outcrop (Fig. 2a) and is composed of hornblende, plagioclase, clinopyroxene and orthopyroxene, with accessory quartz and microcline. Some orthopyroxene grains show exsolution to clinopyroxene and amphibole is retrogressed from pyroxene; therefore, the rock is a partly retrogressed granulite, consistent with granulite-facies rocks with a clinopyroxene-orthopyroxene-plagioclase assemblage occurring adjacent to the sample location. The protolith of the basic granulite was of basaltic composition (Yang et al., 2004).

Zircons are commonly 200-300 $\mu \mathrm{m}$ in diameter, stubby in shape and show sector zoning in CL image (grain 2 in Fig. 3a), being similar to grains commonly formed under granulite-facies conditions (Vavra et 
al., 1999). Some grains show a banded structure with evidence of marginal recrystallization (grain 3 in Fig. 3b), but have the same age as those with sector zoning. Inclusions of pyroxene, apatite (grain 2 in Fig. 3a), feldspar, quartz and $\mathrm{CO}_{2}$ were identified in these zircons. Some calcite was also identified, but this occurs along cracks. These zircons are considered to have formed during granulite-facies metamorphism and are designated here as Meta I. These zircons show overgrowth rims (named Meta II), which are dark in CL and usually narrow in width, so that only a few were wide enough for analysis (Fig. 3a, b, c). A total of 23 analyses were made on 14 zircon grains. Except for spot 11.1 (a Meta I analysis which shows lead loss), the other thirteen Meta I zircon domains give a ${ }^{207} \mathrm{~Pb} /{ }^{206} \mathrm{~Pb}$ weighted mean age of $2510 \pm 8 \mathrm{Ma}$ (MSWD $=$ 3.8) (Fig. 4a). This age is interpreted as the time of granulite-facies metamorphism. The $\mathrm{U}$ and Th contents and $\mathrm{Th} / \mathrm{U}$ ratios show large variations, being 65-4262 ppm, 4-1725 ppm and 0.07-1.10, respectively (Table EA-1). Some analyses show high $\mathrm{Th} / \mathrm{U}$ ratios, which may be a feature of zircons from high-grade metamorphic rocks, especially ultra-high temperature ones (Zhou et al., 2004; Wan et al., 2006; Santosh et al., 2007b). Nine spots were analyzed on the Meta II rims. The $\mathrm{U}$ and $\mathrm{Th}$ contents and $\mathrm{Th} / \mathrm{U}$ ratios range from 221-966 ppm, 101-610 ppm and 0.14-1.37, respectively (Table EA-1). Six of the spots give a ${ }^{207} \mathrm{~Pb} /{ }^{206} \mathrm{~Pb}$ weighted mean age of $2419 \pm 10 \mathrm{Ma}(\mathrm{MSWD}=1.7)($ Fig. 4a) and are considered to represent the time of a subsequent metamorphic event. Two spots (7.1 Meta II and 10.1 Meta II) on rims give ${ }^{207} \mathrm{~Pb} /{ }^{206} \mathrm{~Pb}$ ages of 2340 and $2354 \mathrm{Ma}$ (Fig. 4a). This may record a still later metamorphic event or reflect disturbance by the $\sim 1.9 \mathrm{Ga}$ event, although all rims are similar in CL image and $\mathrm{Th} / \mathrm{U}$ ratio. There appears to be an inherited core in one grain (grain 2 in Fig. 3a) which gives a ${ }^{207} \mathrm{~Pb} /{ }^{206} \mathrm{~Pb}$ age of $2567 \pm 10 \mathrm{Ma}$ (analysis 2.2 in Fig. 4a, Table EA-1).

Fig. 2 here

Fig. 3 here

Fig. 4 here

A meta-basic dyke (sample NM0404) that cuts the two-pyroxene retrogressed granulite (NM0403) described above (Fig. 2a), also experienced the high-grade metamorphic event. It is composed of hornblende, plagioclase, clinopyroxene and orthopyroxene, being similar in mineralogy to the country rock but without quartz and microcline and showing a more homogenous structure. Zircons are rare and occur as small, round or stubby crystals that have a uniform structure in CL images (Fig. 3d), and only 
apatite and $\mathrm{CO}_{2}$ inclusions have been identified. Six spots were analyzed on 6 zircons. The $\mathrm{U}$ and Th contents and $\mathrm{Th} / \mathrm{U}$ ratios range from 695 to $865 \mathrm{ppm}, 118$ to $212 \mathrm{ppm}$ and 0.18 to 0.25 , respectively (Table EA-1). It is difficult to be certain whether the zircons are metamorphic in origin, although they are quite different from those from the two-pyroxene-bearing retrogressed granulite which the dyke cuts. All spots, with the exception of 2.1 which is younger in age (1854 Ma) but shows reverse discordance, give a ${ }^{207} \mathrm{~Pb} /{ }^{206} \mathrm{~Pb}$ weighted mean age of $1924 \pm 11 \mathrm{Ma}(\mathrm{MSWD}=1.8)($ Fig. $4 \mathrm{~b})$. This age is the same as that obtained by Santosh et al. (2007b) for ultra-high temperature metamorphic rocks in the 'Khondalite Belt', so it probably records a metamorphic event, although it is difficult to understand why no metamorphic zircons with this age formed in the adjacent granulite (NM0403).

\section{Wulashan "group'}

A felsic gneiss (sample NM0605) was collected from the leucocratic gneiss sub-unit of the lower Wulashan "group", north of Hademengou (N40 44'08", E109 $38^{\prime} 06^{\prime \prime}$ ) (Fig. 1). It is composed of quartz, K-feldspar, plagioclase and biotite, but shows anatectic features, with reddish veins and patches composed mainly of coarser-grained K-feldspar, plagioclase and quartz (Fig. 2b). Nearby, meta-basic rocks are interlayered with, or occur as pods in the felsic gneiss. Zircon crystals are stubby or tabular in shape and can be divided into two main components: detrital cores and metamorphic (anatectic) rims. Many crystals also show a "core-mantle-rim" structure, with "cores" displaying oscillatory zoning (Fig. 3e). It appears likely that both the "rim" and "mantle" are of metamorphic/anatectic origin, but the "mantles" are too narrow for SHRIMP analysis and so we have not been able to establish this. Seven analyses of "cores" have $\mathrm{U}$ and $\mathrm{Th}$ contents and $\mathrm{Th} / \mathrm{U}$ ratios ranging from 60 to $540 \mathrm{ppm}, 57$ to $538 \mathrm{ppm}$ and 0.34 to 1.13 , respectively (Table EA-1). They vary in apparent age from 2.58 to $2.20 \mathrm{Ga}$ (Fig. 4c), with the oldest being $2582 \pm 17 \mathrm{Ma}$ in age. A few "cores" show a banded structure in CL image (grain 7 in Fig. 3f), and may be detrital magmatic grains. Three analyses of these give $\mathrm{U}$ and $\mathrm{Th}$ contents and $\mathrm{Th} / \mathrm{U}$ ratios of 240 to 448 ppm, 139 to $190 \mathrm{ppm}$ and 0.38 to 0.60 , and show a large variation in ${ }^{207} \mathrm{~Pb} /{ }^{206} \mathrm{~Pb}$ age from 2398 to 2130 Ga (Fig. 4c), probably suggesting that they came from different sources. Eleven analyses of the "rims" have $\mathrm{U}$ and $\mathrm{Th}$ contents and $\mathrm{Th} / \mathrm{U}$ ratios ranging from 310 to $1036 \mathrm{ppm}, 14$ to $72 \mathrm{ppm}$ and 0.02 to 0.1 , respectively (Table EA-1), and vary from 2.48 to $1.78 \mathrm{Ga}$ in age, with seven analyses having a ${ }^{207} \mathrm{~Pb} /{ }^{206} \mathrm{~Pb}$ weighted mean age of $2438 \pm 8 \mathrm{Ma}(\mathrm{MSWD}=1.2)$ (Fig. 4c). These rims show structural and compositional features typical of metamorphic zircon (Vavra et al., 1999; Corfu et al., 2003) and so are 
considered to be formed in this manner. Five other "rim" analyses, with the exception of $21.1 \mathrm{R}$ and $22.1 \mathrm{R}$ which overlap onto cores, give $\mathrm{a}^{207} \mathrm{~Pb} /{ }^{206} \mathrm{~Pb}$ weighted mean age of $1853 \pm 10 \mathrm{Ma}(\mathrm{MSWD}=2.1)(\mathrm{Fig} .4 \mathrm{c})$. This age is interpreted as the age of late Palaeoproterozoic metamorphism and anatexis. One group of "rim" analyses thus have similar ages to several of the "cores",, with only one analysis of the latter being older (Fig. 4c). However, some "core" and "rim" domains give much younger ${ }^{207} \mathrm{~Pb} /{ }^{206} \mathrm{~Pb}$ ages, probably due to the effects of late metamorphism..

A meta-gabbro (sample NM0618) was collected from north of Hujigou (N4053'21", E11004'26") (Fig. 1). Its relationship with the melanocratic gneiss unit of the lower Wulashan "group" is unclear. The gabbro appears to have undergone anatexis with local development of leucocratic neosome (Fig. 2c). Away from the neosome, the gabbro is more homogeneous and medium to coarse grained (Fig. 2d) and is composed of plagioclase, hornblende, biotite and minor quartz. Zircons are prismatic or stubby in shape and show core-rim structures in CL images. Most of the cores are banded (Fig. 3g, h) or show oscillatory zoning (Fig. 3g). Some cores contain feldspar, apatite and quartz inclusions (Fig. 3g, h). Nineteen analyses on the cores have $\mathrm{U}$ and $\mathrm{Th}$ contents and $\mathrm{Th} / \mathrm{U}$ ratios ranging from 72 to $545 \mathrm{ppm}, 64$ to $809 \mathrm{ppm}$ and 0.91 to 1.53 , respectively (Table EA-1). All analyses, except $1.1 \mathrm{C}$ and $4.2 \mathrm{C}$, give a ${ }^{207} \mathrm{~Pb} /{ }^{206} \mathrm{~Pb}$ weighted mean age of $2371 \pm 16 \mathrm{Ma}(\mathrm{MSWD}=2.4)$ (Fig. 4d). The large error and MSWD value may partly reflect disturbance due to later tectonothermal event(s). Metamorphic rims are common, but only a few are wide enough to analyze. They are homogenous or show weak zoning (Fig. 3g), and no mineral inclusions have been identified. Eight spots were analyzed on the rims and the $\mathrm{U}$ and $\mathrm{Th}$ contents and $\mathrm{Th} / \mathrm{U}$ ratios range from 261 to $1476 \mathrm{ppm}, 18$ to $338 \mathrm{ppm}$ and 0.01 to 0.58 , respectively (Table EA-1). They vary widely in ${ }^{207} \mathrm{~Pb} /{ }^{206} \mathrm{~Pb}$ age, with the four youngest analyses giving a ${ }^{207} \mathrm{~Pb} /{ }^{206} \mathrm{~Pb}$ weighted mean age of $1900 \pm 10 \mathrm{Ma}$ $(\mathrm{MSWD}=1.8)($ Fig. $4 \mathrm{~d})$. The slightly older rim ages may be partly due to analytical sites overlapping onto the cores.

A garnet-biotite gneiss (sample NM0413) was collected from a wide homogeneous layer northwest of Maohudong (N40 48'32", E110 $\left.{ }^{\circ} 15^{\prime} 27^{\prime \prime}\right)$ (Fig. 1), where the high-grade metasedimentary rocks are considered to represent typical khondalites of the upper Wulashan "group". The rock shows weak anatexis, giving rise to a quartzo-feldspathic neosome (Fig. 2e). The sample consists of plagioclase, quartz, biotite and garnet: sillimanite was identified in rocks nearby, but was not present in this sample. Zircons are 
round or long-prismatic grains with rounded terminations and show a core-mantle-rim structure, though the mantle is commonly narrow (Fig. 5a and b). The round, detrital grains commonly have wider rims than the elongated ones. Some cores contain apatite, quartz and feldspar inclusions, but the mantles and rims are inclusion-free. Ten spots were analyzed on the cores and all analyses, except 15.1C, have $\mathrm{U}$ and $\mathrm{Th}$ contents and Th/U ratios ranging from 105 to $1882 \mathrm{ppm}, 67$ to $359 \mathrm{ppm}$ and 0.09 to 1.13 , respectively (Table EA-1). They have ${ }^{207} \mathrm{~Pb} /{ }^{206} \mathrm{~Pb}$ ages ranging from 2557 to $2477 \mathrm{Ma}$, with a weighted mean ${ }^{207} \mathrm{~Pb} /{ }^{206} \mathrm{~Pb}$ age of $2513 \pm 19 \mathrm{Ma}(\mathrm{MSWD}=6.1)($ Fig. $4 \mathrm{e})$, suggesting a late Archaean magmatic source region. Fourteen spots were analyzed on the rims and the $\mathrm{U}$ and $\mathrm{Th}$ contents and $\mathrm{Th} / \mathrm{U}$ ratios range from 279 to $1208 \mathrm{ppm}, 5$ to $210 \mathrm{ppm}$ and 0.01 to 0.27 , respectively, with $\mathrm{Th} / \mathrm{U}$ ratio being mostly less than 0.1 (Table EA-1). Except for $12.1 \mathrm{R}, 14.1 \mathrm{R}$ and $18.1 \mathrm{R}$, the remaining eleven analyses give a ${ }^{207} \mathrm{~Pb} /{ }^{206} \mathrm{~Pb}$ weighted mean age of $2397 \pm 10 \mathrm{Ma}(\mathrm{MSWD}=0.4$ ) (Fig. 4e), which is interpreted as dating a subsequent metamorphic event.

Fig. 5 here

A garnet-biotite granite (sample NM0401) from Hademengou (N4042'29", E109'38'34") (Fig. 1) varies in texture, with some localities showing a distinct foliation (Fig. 2f). There are many metasedimentary and some mafic granulite enclaves in the granite, and geological and geochemical studies indicate it formed through anatexis of upper Wulashan "group" metasedimentary rocks (Yang et al., 2004). The biotite is dark brown in colour and contains many needle-shaped titanite inclusions. Zircons are round in shape, $150-200 \mu \mathrm{m}$ in diameter and show complex structures in CL images, generally exhibiting core-mantle-rim structures (Fig. $5 \mathrm{c}$ and d). Most of the cores are characterized by concentric and patchy zoning in CL and are embayed by metamorphic mantles (Fig. $5 \mathrm{c}$ and d). The mantles are dark in CL and show a more uniform structure, with most of them wide enough to analyze. In some zircon grains, the boundary between mantle and core shows an intergrowth of bright and dark features in CL (Fig. $5 \mathrm{c}$ and d), interpreted to be the result of recrystallization, probably under the influence of fluids. The rims are bright in CL and show transitional boundaries with the mantle. Some rims show oscillatory zoning (Fig. 5c), indicating a magmatic origin. Apatite, feldspar and quartz inclusions are present in some cores, suggesting that they formed originally from a granitic magma: no inclusions were found in the mantles and rims. Twelve analyses of the cores have $\mathrm{U}$ and $\mathrm{Th}$ contents and $\mathrm{Th} / \mathrm{U}$ ratios ranging from 50 to 605 
ppm, 33 to 489 ppm and 0.58 to 1.07, respectively (Table EA-1). All core analyses, with the exception of $2.2 \mathrm{C}$ which is much younger in age $(2302 \mathrm{Ma})$, give a ${ }^{207} \mathrm{~Pb} /{ }^{206} \mathrm{~Pb}$ weighted mean age of $2503 \pm 14 \mathrm{Ma}$ $(\mathrm{MSWD}=3.1)($ Fig. $4 \mathrm{f})$. Eleven analyses of mantles show higher $\mathrm{U}$ contents (329 to $1690 \mathrm{ppm})$, lower Th contents (8 to $49 \mathrm{ppm}$ ) and, therefore, very low $\mathrm{Th} / \mathrm{U}$ ratios $(0.01$ to 0.08$)$; with the exception of $11.1 \mathrm{M}$ which has a $\mathrm{Th} / \mathrm{U}$ ratio of 0.31 . All spots, except outlier 17.1 , give $\mathrm{a}{ }^{207} \mathrm{~Pb} /{ }^{206} \mathrm{~Pb}$ weighted mean age of $2445 \pm 10 \mathrm{Ma}(\mathrm{MSWD}=2.5$ ) (Fig. 4f). Sixteen analyses of the rims have $\mathrm{U}$ and $\mathrm{Th}$ contents and $\mathrm{Th} / \mathrm{U}$ ratios ranging from 89 to $175 \mathrm{ppm}, 44$ to $80 \mathrm{ppm}$ and 0.26 to 0.61 , respectively, and give ${ }^{207} \mathrm{~Pb} /{ }^{206} \mathrm{~Pb}$ weighted mean age of $2388 \pm 20 \mathrm{Ma}(\mathrm{MSWD}=4.6$ ) (Fig. 4f). The large error and MSWD may be partly due to some sites overlapping onto mantles. The core ages are interpreted as the formation time of the detrital source rocks $(2.5 \mathrm{Ga})$ to the khondalitic protolith, the mantle ages as the time of high-grade metamorphism of the original khondalitic sedimentary rock $(2.45 \mathrm{Ga})$ and, finally, the rims record anatexis of the khondalite, leading to formation of the late to post-tectonic granite $(2.39 \mathrm{Ga})$.

Another garnet-biotite gneiss (sample NM0405) was collected from a unit previously assigned to the upper Wulashan "group”, north of Maohudong (N4045'37", E110¹9'02") (Fig. 1). It is crudely banded (Fig. 2g) and composed of quartz, plagioclase, biotite, garnet and some K-feldspar. The garnets contain central mineral inclusions of fine-grained quartz, feldspar and light brown biotite; the biotite in the matrix is darker brown in colour. Quartz, plagioclase, K-feldspar and biotite occur as aggregates, possibly a result of strong deformation and recrystallization. The zircons are round or long-prismatic grains and commonly show core-mantle-rim structures (Fig. 5e, f, g). Grain 29 in Figure 5g shows a very complex structure with a mantle exhibiting weak zoning, possibly suggesting an anatectic origin. The cores contain apatite, quartz, feldspar and anatase $\left(\mathrm{TiO}_{2}\right.$ polymorph) inclusions, but no inclusions were identified in the mantles or rims. Based on twenty analyses, the cores have $\mathrm{U}$ and Th contents and Th/U ratios of 57 to $763 \mathrm{ppm}, 18$ to 485 ppm and 0.08 to 0.94 , with most of the ratios being greater than 0.25 (Table EA-1). Eighteen core analyses give a ${ }^{207} \mathrm{~Pb} /{ }^{206} \mathrm{~Pb}$ weighted mean age of $2060 \pm 15 \mathrm{Ma}(\mathrm{MSWD}=1.8)($ Fig. $4 \mathrm{~g})$. Eight analyses of the mantles show large variations of $U$ and Th contents (141 to $572 \mathrm{ppm}$ and 6-98 ppm) and Th/U ratios (0.01 to 0.72 ) and define $\mathrm{a}^{207} \mathrm{~Pb} /{ }^{206} \mathrm{~Pb}$ weighted mean age of $1913 \pm 18 \mathrm{Ma}(\mathrm{MSWD}=2.6)$ (Fig. $4 \mathrm{~g}$ ). Nine analyses of the rims have $\mathrm{U}$ and $\mathrm{Th}$ contents and $\mathrm{Th} / \mathrm{U}$ ratios of 57 to $288 \mathrm{ppm}, 1$ to $60 \mathrm{ppm}$ and 0.02 to 0.34, respectively, and give $\mathrm{a}^{207} \mathrm{~Pb} /{ }^{206} \mathrm{~Pb}$ weighted mean age of $1953 \pm 13 \mathrm{Ma}(\mathrm{MSWD}=0.24$ ) (Fig. $4 \mathrm{~g}$ ).. The mantles are thus apparently younger than the rims. It may be that the mantles and rims formed during 
the same metamorphic event, although it is not possible to constrain which, if either, is the more correct estimate of the timing of this event. There are also narrow outer rims in some zircons and one of these (29.3SR in Fig. 5 g) gives a ${ }^{207} \mathrm{~Pb} /{ }^{206} \mathrm{~Pb}$ age of $1856 \pm 17 \mathrm{Ma}$, with $\mathrm{U}$ and Th contents and $\mathrm{Th} / \mathrm{U}$ ratios being $177 \mathrm{ppm}, 10 \mathrm{ppm}$ and 0.06, respectively (Table EA-1). This age may represent the time of a later metamorphic event, since it is similar to the main event recorded in the Trans-North China Orogen (Zhao et al., 2005).

Meidaizhao "group"

A feldspathic quartzite (NM0414) sample was collected from the Meidaizhao "group" 30km southeast of Shiquai $\left(\mathrm{N} 40^{\circ} 37^{\prime} 19^{\prime \prime}, \mathrm{E} 109^{\circ} 35^{\prime} 02^{\prime \prime}\right)$. It is composed of plagioclase, microcline, quartz, biotite and muscovite. The plagioclase is commonly altered to sericite, and the biotite is chloritized. The mineral assemblage defines greenschist-facies metamorphism, and the rock only shows a weak deformation fabric (Fig. 2h); in this respect it is different from the high-grade metamorphic rocks of the Sanggan and Wulashan "groups". The detrital zircons are commonly small and stubby to prismatic in shape, and oscillatory zoning is clearly observed in CL images (Fig. 5h), indicating that they are of magmatic origin. Narrow metamorphic rims are present in some zircons (grain 9 in Fig. 5h). Twenty-three sites were analyzed on 23 zircons and the $\mathrm{U}$ and Th contents and $\mathrm{Th} / \mathrm{U}$ ratios range from 88 to $590 \mathrm{ppm}, 26$ to 894 ppm and 0.21 to 1.63 , respectively. Two analyses have ${ }^{207} \mathrm{~Pb} /{ }^{206} \mathrm{~Pb}$ ages of 3.15 and $2.48 \mathrm{Ga}$ (18.1 and 9.1), but the remainder are concentrated between 2.3 to 2.1 and at $\sim 2.0 \mathrm{Ga}$ (Fig. 4h). The ten youngest analyses on or close to concordia give a ${ }^{207} \mathrm{~Pb} /{ }^{206} \mathrm{~Pb}$ weighted mean age of $1999 \pm 15 \mathrm{Ma}$ (MSWD $=1.4$ ). This defines the maximum age of deposition of the quartzite.

\section{Hf isotope compositions of zircons}

\section{Sanggan "group"}

The two-pyroxene-bearing retrogressed granulite (NM0403) was investigated for Lu-Hf systematics and a total of 25 analyses were made on 22 zircon grains (Table EA-2). Twenty two analyses on Meta I domains have $\varepsilon_{\mathrm{Hf}}(\mathrm{T})\left(\mathrm{T}=2510 \mathrm{Ma}\right.$, the weighted mean ${ }^{207} \mathrm{~Pb} /{ }^{206} \mathrm{~Pb}$ age of the Meta I domains) ranging from +2.00 to +5.43 and $\mathrm{T}_{\mathrm{DM}}$ model ages of 2743 to $2615 \mathrm{Ma}$ (Fig. 6). Three analyses of Meta II domains have $\varepsilon_{\mathrm{Hf}}(\mathrm{T})\left(\mathrm{T}=2419 \mathrm{Ma}\right.$, the weighted mean ${ }^{207} \mathrm{~Pb} /{ }^{206} \mathrm{~Pb}$ age of the Meta II domains $)$ and $\mathrm{T}_{\mathrm{DM}}$ age 
ranging from +2.92 to +4.19 and 2632 to 2584 Ma, respectively, similar to the Meta I domains.

Fig. 6 here

\section{Wulashan "group"}

The garnet-biotite gneiss (NM0413) was investigated and a total of 35 analyses were made on 29 zircon grains (Table EA-2). Twenty six analyses on detrital cores have $\varepsilon_{\mathrm{Hf}}(\mathrm{T})(\mathrm{T}=2513 \mathrm{Ma}$, the weighted mean ${ }^{207} \mathrm{~Pb} /{ }^{206} \mathrm{~Pb}$ age of the detrital cores) ranging from +0.55 to +5.83 and $\mathrm{T}_{\mathrm{DM}}$ model ages of 2803 to $2603 \mathrm{Ma}$ (Fig. 6), thus showing a larger Hf isotope variation than zircons from the two-pyroxene retrogressed granulite of the Sanggan "group". Nine analyses on metamorphic rims have $\varepsilon_{\mathrm{Hf}}(\mathrm{T})(\mathrm{T}=2397 \mathrm{Ma}$, the weighted mean ${ }^{207} \mathrm{~Pb} /{ }^{206} \mathrm{~Pb}$ age of the metamorphic rims) ranging from +0.86 to +2.28 and $\mathrm{T}_{\mathrm{DM}}$ model ages of 2719 to 2642 Ma (Fig. 6), being similar to those of the detrital cores. This demonstrates that the Lu-Hf isotopic system has not been affected by high-grade metamorphism (Dong et al., 2007).

The garnet-biotite granite (NM0401), considered to be the result of anatexis of upper Wulashan metasedimentary rocks, was investigated and a total of 28 analyses were made on 21 zircon grains (Table EA-2). Twelve analyses on inherited cores have $\varepsilon_{\mathrm{Hf}}(\mathrm{T})\left(\mathrm{T}=2503 \mathrm{Ma}\right.$, the weighted mean ${ }^{207} \mathrm{~Pb} /{ }^{206} \mathrm{~Pb}$ age of the inherited cores) ranging from +0.27 to +5.73 and $\mathrm{T}_{\mathrm{DM}}$ model ages of 2833 to $2598 \mathrm{Ma}$ (Fig. 6), being similar to the detrital cores of zircons from the garnet-biotite gneiss (NM0413) and therefore consistent with the view that the granite formed by anatexis of the metasedimentary rocks. Six analyses on metamorphic mantles have $\varepsilon_{\mathrm{Hf}}(\mathrm{T})\left(\mathrm{T}=2445 \mathrm{Ma}\right.$, the weighted mean ${ }^{207} \mathrm{~Pb} /{ }^{206} \mathrm{~Pb}$ age of the metamorphic mantles) of -0.80 to +2.10 and $\mathrm{T}_{\mathrm{DM}}$ model ages 2802 to $2691 \mathrm{Ma}$, except for analysis $25 \mathrm{M}$, which has a lower $\varepsilon_{\mathrm{Hf}}(\mathrm{T})(-2.76)$ and an older $\mathrm{T}_{\mathrm{DM}}$ age (2875 Ma) (Table EA-2, Fig. 6). Nine analyses on anatectic rims have $\varepsilon_{\mathrm{Hf}}(\mathrm{T})\left(\mathrm{T}=2388 \mathrm{Ma}\right.$, the weighted mean ${ }^{207} \mathrm{~Pb} /{ }^{206} \mathrm{~Pb}$ age of the anatectic rims $)$ and $\mathrm{T}_{\mathrm{DM}}$ ages of -0.37 to +2.50 and 2728 to $2619 \mathrm{Ma}$, respectively. The metamorphic mantles and anatectic rims are therefore similar to the inherited cores, suggesting that the Hf isotope composition of the sources from which the zircons formed was not changed during subsequent metamorphism and anatexis.

Another garnet-biotite gneiss (sample NM0405) was also investigated and a total of 31 analyses were made on 29 zircon grains (Table EA-2). Twenty seven analyses on detrital cores have $\varepsilon_{\mathrm{Hf}}(\mathrm{T})(\mathrm{T}=2060 \mathrm{Ma}$, 
the weighted mean ${ }^{207} \mathrm{~Pb} /{ }^{206} \mathrm{~Pb}$ age of the core) ranging from +1.50 to +7.35 and $\mathrm{T}_{\mathrm{DM}}$ model ages of 2380 to $2153 \mathrm{Ma}$. The large positive $\varepsilon_{\mathrm{Hf}}(\mathrm{T})$ values show that the source region has no relationship to the older rocks in the area (Fig. 6). A few analyses on metamorphic mantles and rims have similar Hf isotope compositions to the detrital cores (Fig. 6), indicating that the Lu-Hf isotope systematics were not affected by metamorphism. The protolith of this garnet-bearing gneiss thus sampled an entirely different source region to garnet gneiss sample NM0413.

\section{Discussion}

The new SHRIMP U/Pb zircon dating, combined with the zircon $\mathrm{Hf}$ isotope study, indicates a thorough reassessment of the Khondalite Belt is required. Our data show new complexities in the depositional and metamorphic history as summarized in Table 1 , and indicates that the previous stratigraphic division needs to be revised.

Table 1 here.

Source and depositional ages of the supracrustal rocks in the Daqingshan area

Sanggan "group": The two-pyroxene-bearing retrogressed granulite (NM0403) has an age of $2.51 \pm 0.01$ Ga for the Meta I zircon domains and this is interpreted as the time of granulite-facies metamorphism of the Sanggan "group". An inherited-core-like domain in one zircon grain (grain 2 in Fig. 3a) gives a ${ }^{207} \mathrm{~Pb} /{ }^{206} \mathrm{~Pb}$ age of $2567 \pm 10 \mathrm{Ma}$, which may record the magmatic age of the rock, although more data are required to establish this. The Meta I zircon domains show large variations in $\mathrm{Lu} / \mathrm{Hf}$, but with $\mathrm{eHf}_{(\mathrm{T})}$ being generally positive and ranging from +2.00 to +5.43 . These results indicate that the Sanggan "group" in the Daqingshan area formed during the Neoarchaean, not Palaeoarchaean, as previously thought.

Wulashan "group": Zircons from anatectic felsic gneiss sample (NM0605) from the leucocratic gneiss unit of the lower Wulashan "group" show complex variations in texture and age, with most zircons showing “core-mantle-rim" structures. The homogenous or weakly zoned "rims" give a ${ }^{207} \mathrm{~Pb} /{ }^{206} \mathrm{~Pb}$ weighted mean age of $2.44 \pm 0.01 \mathrm{Ga}$ which may represent the time of metamorphism of the source region. The youngest detrital "core" gives a ${ }^{207} \mathrm{~Pb} /{ }^{206} \mathrm{~Pb}$ age of $2.13 \pm 0.02 \mathrm{Ga}$, which limits the time of deposition to between 
2.13 and $1.85 \mathrm{Ga}$, the latter being the age of the metamorphic rims. No ages have been determined for the mesocratic gneiss unit of the lower Wulashan "group".

Detrital and metamorphic zircons from garnet-biotite gneiss (NM0405) give ${ }^{207} \mathrm{~Pb} /{ }^{206} \mathrm{~Pb}$ weighted mean ages of $2.06 \pm 0.02 \mathrm{Ga}$ and $1.95 \pm 0.01 \mathrm{Ga}$, respectively, limiting the time of deposition of the khondalite precursors of the upper Wulashan "group" to late Palaeoproterozoic and not Mesoarchaean as previously suggested. This is consistent with the geochronological study of Santosh et al. (2007b), who obtained detrital core and metamorphic rim ages of zircons from UHT rocks in the Zhuozi-Tuguiwula area in the eastern segment of the Khondalite Belt, of $\sim 1.97$ and $1.92 \mathrm{Ga}$, respectively. Based on detrital zircon ages, Xia et al. (2006a, b) drew a similar conclusion from central and eastern segments of the Khondalite Belt. However, these latter authors considered that the protolith of the khondalites was deposited after $1.84 \mathrm{Ga}$. This is not consistent with evidence that metamorphism occurred between 1.95 and $1.85 \mathrm{Ga}$ (Wan et al., 2006; Santosh et al., 2007a, b; Dong et al., 2007; this study) and that the khondalite was intruded by diorite with a zircon age of $1.92 \mathrm{Ga}$ (Gou et al., 2002).

It is therefore evident that most khondalites were deposited during the late Palaeoproterozoic (Fig. 1, Xia et al., 2006a, 2006b; Santosh et al., 2007a, 2007b; Dong et al., 2007; this study). However, garnet-biotite gneiss sample NM0413 has detrital and metamorphic zircon ages of $2.51 \pm 0.02 \mathrm{Ga}$ and 2.40 $\pm 0.01 \mathrm{Ga}$, respectively, suggesting that the protolith of some khondalites was deposited during the earliest Palaeoproterozoic. This is further supported by dating of the garnet-biotite granite (NM0401), which intrudes some metasedimentary rocks of the upper Wulashan "group" at $~ 2.39 \mathrm{Ga}$ (the age of zircon rims with some showing magmatic zoning, Fig. 5c, d). The metamorphic zircon mantles in this granite record a slightly older age of $2.46 \pm 0.01 \mathrm{Ga}$, further limiting the deposition time of the sedimentary rocks to between 2.51 and $2.46 \mathrm{Ga}$. Since the garnet-biotite gneiss (NM0413) is interlayered with other high-grade rocks assigned to the Sanggan and Wulashan "groups", it appears that gneisses of different age have been juxtaposed during later deformation; a feature commonly observed in Precambrian terrains worldwide.

Meidaizhao "group": Xu et al. (2003) suggested that the Meidaizhao "group" formed during the late Palaeoproterozoic. Although metamorphic zircon ages could not obtained from the sample of feldspathic quartzite (NM0414), because there was no new zircon growth owing to the low grade of metamorphism, 
the youngest detrital zircon age $(2.00 \pm 0.02 \mathrm{Ga})$ may support this view. In addition, 1) no regional metamorphism occurred after the Palaeoproterozoic in the study area and, 2) the Meidaizhao "group" metasediments were intruded by post-orogenic granite at $1.82 \pm 0.01 \mathrm{Ga}$ (Xu et al., 2003). On the basis of geological mapping, Xu et al. (2003) indicated that the Meidaizhao "group" rests unconformably on the khondalites. This implies that the age of the underlying khondalite was greater than $2.0 \mathrm{Ga}$.

The Precambrian supracrustal rocks in the Daqingshan area can now be divided into at least three units in terms of their formation age: 1) The $2.56-2.51 \mathrm{Ga}$ supracrustal unit which is equivalent to the original Sanggan "group" and is mainly composed of basic-intermediate-acid volcano-sedimentary rocks at granulite facies. Rocks of the same age are widely distributed in the Jining area, east of Daqingshan (Gou et al., 2003) and in the Yinshan Block, north of the Khondalite Belt (Jian et al., 2005; Chen, 2007). 2) The 2.51-2.45 Ga supracrustal unit was originally considered to belong to the khondalite sequence of the upper Wulashan "group" (Yang et al., 2004) but this has now been shown to be incorrect. The detritus may have come from 2.6-2.5 Ga basement rocks which underwent high-grade metamorphism prior to erosion. More work is required to identify their spatial distribution and to distinguish them from the late Palaeoproterozoic khondalites. 3) The 2.0-1.95 Ga supracrustal unit which includes the original lower Wulashan "group", most of the khondalites of the upper Wulashan "group" and the Meidaizhao "group". It is still necessary to investigate whether all the lower Wulashan "group" rocks belong to this unit, since we can only limit the age of formation to the leucocratic gneisses within an age range of 2.13 and $1.85 \mathrm{Ga}$. The late Palaeoproterozoic rocks of the upper Wulashan and Meidaizhao "groups" formed during the same period, but the former are high-grade and strongly deformed whereas the latter are low-grade and only weakly deformed. This phenomenon has also been observed in other orogenic belts, such as the Jingshan and Fenzhishan "groups" in eastern Shandong province (Wan et al., 2006).

\section{Neoarchaean and Palaeoproterozoic tectonothermal events in the Daqingshan area}

Strong and periodical tectonothermal (magmatic or/and metamorphic) events occurred during the late Neoarchaean and Palaeoproterozoic in the Daqingshan area (Table 1) and can be divided into four phases, namely, at 2.6-2.5 Ga, 2.45-2.37 Ga, 2.3-2.0 Ga and 1.95-1.85 Ga. 


\section{6-2.5 Ga event}

Only a few zircon grains with ages of 2.6-2.55 Ga have been identified in this study. However, zircons from different rocks in the Daqingshan area record ages of $\sim 2.5 \mathrm{Ga}$, and most of them are of detrital or inherited origin (Table 1). The most important is the metamorphic age of $2.51 \mathrm{Ga}$ determined from two-pyroxene-bearing retrogressed granulite sample NM0403, which indicates that high-grade metamorphism occurred at the end of the Archaean. A strong $2.5 \mathrm{Ga}$ event has also been recorded in the Yinshan Block, north of the Khondalite Belt, including the 2.5 Ga Seertershan ("group") greenstone belt, which was considered to have formed by a combination of subduction and mantle plumes (Chen, 2007), and TTG granites that show island arc geochemical features and contain old inherited zircons (Jian et al., 2005). However, it is still debatable whether the $\sim 2.5$ Ga tectonothermal event, that occurred widely in the NCC, represents arc magmatism that culminated in collisional orogeny or reflects underplating from mantle plumes (Liu et al., in press).

\subsection{5-2.37 Ga event}

This event can be subdivided into three stages: high-grade metamorphism $(2.45 \mathrm{Ga})$, anatexis $(2.40 \mathrm{Ga})$ and basic magmatism $(2.37 \mathrm{Ga})$. The occurrence of $~ 2.4 \mathrm{Ga} \mathrm{U}-\mathrm{Pb}$ zircon ages is rare in the NCC, being recognized only in a few areas such as in northern Hebei (Liu et al., in press). Both the Archaean basement (represented by sample NM0403 from the Sanggan "group") and the early Palaeoproterozoic supracrustal unit (represented by sample NM0413 from the original upper Wulashan "group") were involved in the 2.45-2.37 Ga event. However, based on CL images and U-Pb dating of detrital zircons, the metamorphic event at $\sim 2.45 \mathrm{Ga}$ occurred in the source region from which some late Palaeoproterozoic sediments were derived (represented by sample NM0605 from the original lower Wulashan "group") and so pre-dated deposition. Metasedimentary rocks (sample NM0413) from the early Palaeoproterozoic supracrustal unit show relatively high maturity. However, the age gap between detrital and metamorphic zircons is only $\sim 50 \mathrm{Ma}$, possibly suggesting that these rocks were deposited in an active continental margin or back-arc environment (Kimbrough et al., 2001). The garnet biotite granite (NM0401) is the first early Palaeoproterozoic crustally-derived granite identified in the area and formed at $2.39 \mathrm{Ga}$ (age of magmatic, anatectic zircon rims), although it still retains evidence of $\sim 2.5 \mathrm{Ga}$ detrital zircon cores. 2.45 
Ga metamorphic mantles may reflect metamorphism of the source area prior to deposition. However, it is also possible that they record metamorphism after deposition of the sediments. We suggest that the magmatic zircon age of $\sim 2.4$ Ga reflects the time when the continental crust underwent regional extension because of crustal uplift resulting from mantle underplating. This is supported by the geochemical features of the 2.37 Ga meta-gabbro (NM0618) which is high in $\mathrm{SiO}_{2}$ and low in $\mathrm{MgO}$, characterized by high REE contents $($ TREE $=351 \mathrm{ppm})$ and fractionation of LREE and HREE $((\mathrm{La} / \mathrm{Yb}) \mathrm{n}=19.7)$, with weak Eu anomaly $\left(\mathrm{Eu}_{\mathrm{Eu}} \mathrm{Eu}^{\mathrm{N}} \mathrm{0.77}\right)$ and a negative $\mathrm{Nb}$ anomalies (Wan et al., unpublished data). These compositional features suggest that the basic magma underwent strong fractionation (and continental contamination?) before crystallization of the gabbro. Therefore, it is possible that the mantle-derived magma may have resided for a long time at the base of the crust before it was emplaced into the upper crust. We therefore suggest that magmatic underplating probably caused the high temperature metamorphism and anatexis at 2.45-2.4 Ga.

\section{3-2.0 Ga event}

Although rocks with 2.3-2.0 Ga ages have not been identified in the Daqingshan area, many metasedimentary rocks of late Palaeoproterozoic age contain detrital zircons with these ages, and most are $\sim 2.0 \mathrm{Ga}$, similar to results obtained by Xia et al. (2006b). There are also abundant 2.3-2.0 Ga detrital zircons in Palaeoproterozoic metasedimentary rocks in other parts of the Khondalite Belt, and the proportion is commonly higher than that of Archaean detrital zircons (Wan et al., 2006; Xia et al., 2006a, 2006b; Dong et al., 2007). In the Qianlishan area, north of Helanshan, detrital zircons from Neoproterozoic to Mesozoic sedimentary rocks reveal an important age peak around 2.00-2.06 Ga (Darby and Gehrels, 2006). Therefore, there must have been an extensive source composed of Palaeoproterozoic igneous rocks which provided the detritus. It remains unclear where the 2.3-2.0 Ga detritus came from (the Ordos massif, Khondalite Belt or somewhere else, Xia et al., 2006a, 2006b; Dong et al., 2007). Zhong et al. (2005a) identified 2.33-2.13 Ga MgO-rich granites in the Khondalite Belt and suggested an island arc environment, similar to that of the Closepet granite in southern India (Moyen et al., 2001).

\subsection{5-1.85 Ga event}


A major, complex tectonothermal event occurred in the Daqingshan area during the late Palaeoproterozoic. Three metamorphic (including anatectic) ages have been identified in this study, namely $\sim 1.95 \mathrm{Ga}, \sim 1.90$ $\mathrm{Ga}$ and $\sim 1.85 \mathrm{Ga}$. Interestingly, these ages have not been recorded in the Neoarchaean mafic volcanic precursor to the two-pyroxene retrogressed granulite (sample NM0403), but this does not necessarily mean that the rock was not involved in the event since, in the Jining area east of Daqingshan, Archaean rocks were affected by the late Palaeoproterozoic event (Gou et al., 2005). The $1.95 \mathrm{Ga}$ metamorphism in the Khondalite Belt resulted in anatexis of carbonates of the upper Wulashan "group" to form crustally derived carbonate-rich magmatic rocks (Wan et al., in review). A $1.90 \mathrm{Ga}$ metamorphic event also occurred in the Khondalite Belt, with the 1.92-1.90 ages interpreted as the time of continent-continent collision (Santosh et al., 2007b). This is slightly earlier than collision of the Trans-North China Orogen (1.88-1.85 Ga) (Zhao et al., 2000, 2002; Guan et al., 2002; Kröner et al., 2005a, 2005b, 2006; Wan et al., 2006). This supports the idea that the three blocks of the NCC were assembled during a single complex event, with the Yinshan and Ordos blocks colliding first, followed slightly later by juxtaposition of the Eastern and Western blocks along the Trans-North China Orogen (Zhao et al., 2003, 2005; Wan et al., 2006; Dong et al., 2007).

Although different "groups" in the Khondalite Belt are distributed separately in space, they commonly appear to be interlayered, especially near the boundaries between the different "groups" (Yang et al., 2003). The rocks have commonly undergone strong metamorphism and deformation and it is difficult to identify a stratigraphy in many cases, implying they occur as tectonic slices. It appears likely that the late Palaeoproterozoic collisional event led to the structural interdigitation of these units, since no strong tectonothermal event has been recognized in the area after the Palaeoproterozoic. More work is required to test this hypothesis.

Protoliths of khondalites are commonly considered to have been deposited in stable environments, such as at passive continental margins or in cratonic basins, based on their high maturity (Condie et al., 1992; Wan et al., 2000). However, the high-grade metamorphism indicates that they must once have been at a deep crustal level. The sequence of events may be summarized as follows: protoliths of khondalites were deposited at a passive continental margin, plate motion drove it interact with another continent with an active continental margin and, finally, the passive margin was subducted below the active margin, 
resulting in high-grade metamorphism of the sediments. In this scenario, the detritus making up the khondalite protolith would have come from an old continent, therefore most of the detrital zircons should be much older than the depositional age of the sediments. In the Daqingshan area, however, the late Palaeoproterozoic khondalites of the upper Wulashan "group" contain detrital zircons as young as $~ 2.06$ $\mathrm{Ga}$, but were deposited between $\sim 2.0$ and $1.95 \mathrm{Ga}$, with only a relatively short time gap of $\sim 50 \mathrm{Ma}$. This suggests that the sediments were deposited in an active continental margin or back-arc setting (Kimbrough et al., 2001), consistent with other features of the total rock assemblage of the Wulashan "group".

Ultra-high temperature (UHT) metamorphism occurs in many orogens and is considered to result from underplating/intraplating of mafic magmas or upwelling of asthenospheric mantle (Santosh et al., 2007b). Recently, Guo et al. (2006) carried out petrological studies on the Daqingshan UHT sapphirine granulites. The metamorphic peak was determined to be at $910-980{ }^{\circ} \mathrm{C}$ and 7.1-9.2 kbar (Guo et al., 2006) with a clock-wise P-T path (Jin et al., 1991; Liu et al., 2000), and a metamorphic age of 1.85 Ga (Guo et al., 2006). In the Khondalite Belt, metamorphism of this age has been identified by Dong et al. (2007) and in this study. At Jining, Santosh et al. (2006, 2007a, 2007b) reported UHT (>900 ${ }^{\circ} \mathrm{C}$ and $\left.9-12 \mathrm{kbar}\right)$ metamorphic rocks, including sapphirine-bearing and spinel-bearing assemblages. Based on detailed petrographical and geochronological studies, they determined the time of metamorphism as $1.92 \mathrm{Ga}$ (three zircon samples and one monazite sample), being 70 Ma older than the metamorphic age obtained by Guo et al. (2006). However, Santosh et al. (2006) had previously obtained monazite ages of $1819 \pm 11 \mathrm{Ma}$ from the 1.92 Ga UHT rocks, suggesting that they had been influenced by a later tectonothermal event: this may have also affected rocks in the present study. More data, including spatial distribution of the UHT rocks, are required in order to resolve this issue.

The Palaeoproterozoic geological evolution of the Daqingshan area can therefore be divided into two main phases: at 2.5-2.37 Ga and 2.3-1.85 Ga. These probably represent two collision-extensional events during the Palaeoproterozoic. The 1.95-1.85 Ga tectonothermal event widely recorded in the Daqingshan area is similar to tectonothermal events recognized in other areas of the NCC and considered to lead to the formation of the NCC (Zhao et al., 2002, 2004, 2005; Guo et al., 2005; Kröner et al.,2005; Wan et al., 2006; Dong et al., 2007). These events have also been identified in other parts of the world (Hoffman, 1988; Rosen et al., 1994; Clowes et al., 2000; Lee et al., 2000; Hartmann, 2002), being consistent with the 
assembly of the Palaeoproterozoic supercontinent Columbia (Rogers and Santosh, 2002; Zhao et al., 2002; Santosh et al., 2007a, 2007b).

An age histogram (Fig. 7) based on published zircon data from the Khondalite Belt and those from this study allows us to make the following comments: 1) There were strong tectonothermal events between 2.5 and $2.3 \mathrm{Ga}$ in the late Neoarchaean to early Palaeoproterozoic; 2) there is no evidence of tectonothermal activity between $2.3-2.15 \mathrm{Ga}$, although a few low quality ages have been reported (Table 2); 3 ) there are some $2.0 \mathrm{Ga}$ magmatic zircons, whose igneous hosts may possibly be the source of the late Palaeoproterozoic sedimentary rocks; 4) strong metamorphic and weaker magmatic events occurred during the late Palaeoproterozoic. The Palaeoproterozoic age distribution for the Khondalite Belt, as shown in Fig. 7, is different from that outside the Khondalite Belt as summarized by Wan et al. (2006), with the later showing a strong peak between 2.2 and $2.05 \mathrm{Ga}$. However, both are similar in that there is an age gap between 2.3 and $2.2 \mathrm{Ga}$.

Table 2 here

Fig. 7 here

Crustal addition during the late Neoarchaean to late Palaeoproterozoic

The Hf isotope data of zircons from four samples in this study can broadly be divided into two groups in terms of formation ages. One includes samples NM0403, NM0413 and NM0401 with Archaean and early Palaeoproterozoic ages, and the second is represented by sample NM0405 of late Palaeoproterozoic age (Fig. 6). In the first group, Meta I zircons from the two-pyroxene-bearing retrogressed granulite from the Sanggan "group" are metamorphic in origin, their $\varepsilon_{\mathrm{Hf}}(\mathrm{T})$ and $\mathrm{Hf}$ model ages are 2.0 to 5.4 and 2.74 to $2.62 \mathrm{Ga}$, respectively, possibly reflecting the $\mathrm{Hf}$ isotopic feature of the precursor volcanic rock. Detrital and inherited zircons from garnet-biotite gneiss from the Wulashan "group", and garnet-biotite granite which was derived from this "group", have ${ }^{207} \mathrm{~Pb} /{ }^{206} \mathrm{~Pb}$ ages of $\sim 2.5 \mathrm{Ga}$ and show very similar $\mathrm{Hf}$ isotope compositions (Table EA-2, Fig. 6). This suggests that: (1) the detrital and inherited zircons were originally from a source region similar in Hf isotopic composition to the Archaean basement; therefore, (2) a large amount of material in the Daqingshan and adjacent areas was derived from a mantle source at the end of 
the Archaean; and (3) the mantle-derived material might be partly contaminated by continental crust because their zircon $\varepsilon_{\mathrm{Hf}}(\mathrm{T})$ values vary largely, with some being close to 0 (Fig. 6).

The $~ 2.06$ Ga detrital zircon cores from the late Palaeoproterozoic metasedimentary rock (NM0405) have $\varepsilon_{\mathrm{Hf}}(\mathrm{T})$ of 1.5 to 7.4 and $\mathrm{T}_{\mathrm{DM}}$ of 2.38 to $2.15 \mathrm{Ga}$ (Table EA-2, Fig. 6). The large variation in positive $\varepsilon_{\mathrm{Hf}}(\mathrm{T})$ suggests there was strong mantle addition in the source region at about $2.0 \mathrm{Ga}$, with some continental contamination, a conclusion also drawn by Xia et al. (2006a). Some $\sim 2.0 \mathrm{Ga}$ detrital zircons analysed by Xia et al. (2006a) gave very negative $\varepsilon_{\mathrm{Hf}}(\mathrm{T})$ values, suggesting they were derived from a source region characterised by recycling of continental crust. The Hf isotopic composition of the meta-gabbro sample (NM0618) has not been analysed in this study, however, the geochemical features of this rock indicate that mantle addition occurred at $2.37 \mathrm{Ga}$. .Therefore, there were at least three periods of mantle addition recorded in the Daqingshan area during the late Neoarchaean to late Palaeoproterozoic $(2.55-2.5 \mathrm{Ga}, \sim 2.37 \mathrm{Ga}$ and $\sim 2.06 \mathrm{Ga})$.

\section{Conclusions}

The early Precambrian supracrustal rocks of the Daqingshan area can be divided into three main groups: the 2.56-2.51 Ga, 2.50-2.45 Ga and 2.0-1.95 Ga supracrustal units. However, these do not correlate with the previous interpretation of the geology that subdivided the rocks into a stratigraphic succession that was composed in part of, from the base upward, the Sanggan, Wulashan and Meidaizhao Groups. Our new results show that the Sanggan "group" formed during the Neoarchaean (not Palaeoarchaean) and the Wulashan "group" during the Palaeoproterozoic (not Mesoarchaean), as previously believed. We have also identified, for the first time, early Palaeoproterozoic metasedimentary rocks forming a unit within the Wulashan "group". This study does, however, support the view of Xu et al. (2003) that the Meidaizhao "group" formed during the Palaeoproterozoic and not in the Archaean.

Some zircons show complex internal structures and record different ages, indicating that they underwent several stages of growth/recrystallization., They enable four tectonothermal events to be recognized in the Daqingshan area, each recording an important stage in the evolution of the Precambrian crust. The events are at 2.6-2.5 Ga, 2.45-2.37 Ga, 2.3-2.0 Ga and 1.95-1.85 Ga, with the latest event being consistent with 
the formation of the NCC and the assembly of the Palaeoproterozoic supercontinent Columbia.

Furthermore, there were at least three periods of mantle addition to the crust, based on the hafnium zircon data from the Daquingshan area: at 2.55-2.5 Ga, 2.37 Ga and 2.06 Ga. Whereas most samples record recycling of $\sim 2.6 \mathrm{Ga}$ Archaean crust, garnet-biotite gneiss NM0405 contains 2.06 Ga zircons that have $\varepsilon_{\mathrm{Hf}}(\mathrm{T})$ values of 1.5 to 7.4 and $\mathrm{T}_{\mathrm{DM} 1}$ model ages of 2.38 to $2.15 \mathrm{Ga}$, indicating a later mantle extraction event. Although no Hf isotope data were obtained for the 2.37 Ga meta-gabbro (NM0618), it is likewise interpreted as being derived from the mantle.

Zircon data obtained by others from the Khondalite Belt show a similar age distribution to the Daqingshan area in this study, but with a stronger age peak at $\sim 1.8 \mathrm{Ga}$. The ages of 1.9-1.85 Ga and 1.85-1.80 Ga reflect collision and extension of the Khondalite Belt, respectively, being consistent with the assembly and breakup of the Palaeoproterozoic supercontinent Columbia.

Acknowledgments

We thank H. Tao, Q.D. Zhang and Q. Ye for making the zircon mounts; Y.H. Zhang and Z.Q. Yang for help with SHRIMP U-Pb dating; L.W. Xie and Y.H. Yang for help with LA-ICP-MS Hf data collection; and H. Yong and L. Yan for help with Raman spectroscopy. We also thank A. Nutman, A. Kröner, Y. Rojas-Agramonte, G.C. Zhao, M. Sun, X.P. Xia, J.S. Wu, Q.H. Shen, J.S. Ren, Y.S. Geng, C.H. Yang, X.Y. Yin, L.L. Du, S.W. Liu, F.Y. Wu, J.H. Gou, M.G. Zhai, S.N. Lu, C.T. Zhong, J.J. Li, C.S. Liu, H.T. Xin for their valuable discussions and assistance during the research. We thank Dr G.C. Zhao and Prof. M. Santosh for their valuable comments. This manuscript is a contribution to IGCP project 509 (Palaeoproterozoic Supercontinents and Global Evolution). The study was supported financially by the Key Program of the Land and Resource Ministry of China (1212010711815), the Programs of the Beijing SHRIMP Centre and the State Key Laboratory of Lithospheric Evolution, Institute of Geology and Geophysics, Chinese Academy of Sciences.

\section{References}

Black, L.P., KAMO, S.L., Allen, C.M., AleinikOFF, J.N., DAVIS, D.W., KORSCH, R.J. \& FOUdOUliS, C. 2003. TEMORA 1: a new zircon standard for Phanerozoic U-Pb geochronology. Chemical 
Geology. 200, 155-170.

BLEEKER, W. 2003. The late Archaean record: a puzzle in ca. 35 pieces. Lithos, 71, 99-134.

BLICHERT-TOFT, J. \& ALBAREDE, F. 1997. The Lu-Hf geochemistry of chondrites and the evolution of the mantle-crust system. Earth and Planetary Science Letters, 148, 243-258.

BRIAN, J.D. \& GEORGE, G. 2006. Detrital zircon reference for the North China block. Journal of Asian Earth Sciences, 26, 637-648.

Chacko, T., Kumar, G.R., MeEn, J.K. \& Rogers, J.J.W. 1992. Geochemistry of high-grade supracrustal rocks from the Kerala Khondalite Belt and adjacent massif charnockites, South India. In: van REENEN, D.D., ROERING, C. \& ASHWAL, L.D. (ed.) The Archaean Limpopo Granulite Belt: Tectonics and Deep Crustal Processes. Precambrian Research, 55, 469-489.

CHEN, L. 2007. Geochronology and geochemistry of the Guyang Greenstone Belt. Post-Doctor Report. Institute of Geology and Geophysics, Chinese Academy of Sciences, Beijing, p. 1-40.

Clowes, R., CoOK, F., HaJnal, Z., Hall, J., Lewry, J., LuCAS, S. \& WARdLe, R., 2000. Canada's LITHOPROBE project (collaborative, multidisplinary geoscience research leads to new understanding of continental evolution). Episodes, 22, 4-20.

CONDIE, K.C., BORYTA, M.D., LIU, J.Z. \& QIAN, X.L., 1992. The origin of khondalites: geochemical evidence from the Archaean to Early Proterozoic granulite belt in the North China Craton. Precambrian Research, 59, 207-223.

CORfU, F., HANCHAR, J.M., HOSKIN, P.W.O. \& KINNY P., 2003. Atlas of zorcon textures, in: HANCHAR, J.M., and Hoskin, P.W.O., editors, Zircon: Mineralogical Society of America, Washington, p. 469-500.

DARBY, B.J. \& GEHRELS, G., 2006. Detrital zircon reference for the North China block. Journal of Asian Earth Sciences, 26, 637-648.

DONG, C.Y., LIU, D.Y., LI, J.J., WAN, Y.S., ZHOU, H.Y., LI, C.D., YANG, Y.H. \& XIE, L.W., 2007. Palaeoproterozoic Khondalite Belt in the Western North China Craton: New evidence from SHRIMP dating and Hf isotope composition of zircons from metamorphic rocks in the Bayanwula-Helanshan area. Chinese Science Bulletin (in press).

GENG, Y.H., LIU, D.Y. \& SONG, B. 1997. Chronological framework of the early Precambrian important events of the Northwestern Hebei granulite terrain. Acta Geologica Sinica, 71, 316-327 (in Chinese with English abstract). 
GuAN, H., Sun, M., WILDE, S.A., ZHOU, X.H. \& ZHAI, M.G., 2002. SHRIMP U-Pb zircon geochronology of the Fuping Complex: implications for formation and assembly of the North China Craton. Precambrian Research, 113, 1-18.

GUO, J.H., SHI, X., BIAN, A.G., XU, R.H., ZhAI, M.G. \& LI, Y.G. 1999. Pb isotopic composition of feldspar and $\mathrm{U}-\mathrm{Pb}$ age of zircon from early Proterozoic granite in Sanggan area North China craton: Metamorphism crustal melting and tectono-thermal event. Acta Petrologica Silica, 15, 199-207 (in Chinese with English abstract).

GUO, J.H., ZHAI, M.G. \& XU, R.H. 2002. Timing of granulite facies metamorphism occurring widely in the Sanggan area, North China: Zircon U-Pb geochronology. Science in China, 32, 10-18.

GUO, J.H., SUN, M. CHEN, F.K. \& ZHAI, M.G. 2005. Sm-Nd and SHRIMP U-Pb zircon geochronology of high-pressure granulites in the Sanggan area, North China Craton: timing of Palaeoproterozoic continental collision. Journal of Asian Earth Sciences, 24, 629-642.

Guo, J.H., Chen, Y., Peng, P., LiU, F., Chen, L. \& Zhang, L.Q. 2006. Sapphirine granulite in the Daqingshan area, Inner Mongolia: 1.8 Ga ultra-high temperature (UHT) metamorphism. Abstract, Conference on Petrology and Geodynamics, p. 215-218.

HARTMANN, L.A., 2002. The Mesoproterozoic supercontinental Atlantica in the Brazilian shield-review of geological and U-Pb zircon and Sm-Nd isotopic evidence. Gondwana Research, 5, 157-163.

HOFFMAN, P.F., 1988. United plates of America, the birth of a craton: early Proterozoic assembly and growth of Laurentia. Annual Review of Earth Planetary Sciences, 16, 543-603.

HU, N.G., YANG, J.X., WANG, Z.B., WANG, T. \& LI, W.P. 1994. The composition and evolution of complex in Helanshan. Xi'an Map Publishing House, Xi'an, p. 1-59 (in Chinese).

JIAN, P., ZHANG, Q., LIU, D.Y., JIN, W.L., JIA, X.Q. \& QIAN, Q. 2005. SHRIMP dating and geological significance of late Archaean high-Mg diorite (sanukite) and hornblende-granite at Guyang of Inner Mongolia. Acta Petrologica Sinica, 21, 151-157 (in Chinese with English abstract).

JIN, W., LI, S.X. \& LIU, X.S. 1991. A study on characteristics of early Precambrian high-grade metamorphic rock series and their metamorphic dynamics. Acta Petrologica Sinica, 4, 27-35 (in Chinese with English abstract).

Kimbrough, D.L., SMith, D.P., Mahoney, J.B., MoORe, T.E., Grove, M., GaStil, R.G., ORTEGA-RIVERA, A. \& FANNING, C.M. 2001. Forearc-basin sedimentary response to Rapid Late Cretaceous batholith emplacement in the Peninsular Ranges of southern and Baja California. Geology, 29, 491-494. 
KRÖNER, A., WILDE, S.A., LI, J.H. \& WANG, K.Y. 2005a. Age and evolution of a late Archaean to Palaeoproterozoic upper to lower crustal section in the Wutaishan/Hengshan/Fuping terrain of northern China. Journal of Asian Earth Science, 24, 577-595.

KRÖNER, A., WILDE, S.A., O’BRIEN, P.J., LI, J.H., PASSCHIER, C.W., WALLE, N.P., LIU, D.Y., 2005b, Field Relationships, Geochemistry, Zircon Ages and Evolution of a Late Archaean to Palaeoproterozoic Lower Crustal Section in the Hengshan Terrain of Northern China. Acta Geologica Sinica, 79, 605-629.

KrÖNER, A., WiLDE, S.A., ZHAO, G.C., O’BrIEN, P.J., SuN, M., LiU, D.Y., WAN, Y.S., LIU, S.W. \& GUO, J.H., 2006. Zircon geochronology and metamorphic evolution of mafic dykes in the Hengshan Complex of northern China: Evidence for late Palaeoproterozoic extension and subsequent high-pressure metamorphism in the North China Craton. Precambrian Research, 146, 45-67.

KUSKY, T.M. \& LI, J.H., 2003. Paleoproterozoic tectonic evolution of the North China Craton. Journal of Asian Earth Sciences 22, 383-397.

KuSKY, T., LI, J.H. \& SANTOSH, M., 2007. The Paleoproterozoic North Hebei Orogen: North China craton's collisional suture with the Columbia supercontinent. Gondwana Research, 12, 4-28.

LEE S.R., CHO, M., YI, K., STERN, R.A., 2000. Early Proterozoic granulites in Central Korea: tectonic correlation with Chinese cratons. Journal of Geology, 108, 729-738.

LI, J.H., KUSKY, T.M., HUANG, X., 2002. NeoArchaean podiform chromitites and harzburgite tectonite in ophiolitic melange, North China craton, remnants of Archaean oceanic mantle. GSA Today, 12, $4-11$.

LI, J.J., SHEN, B.F., LI, H.M., ZHOU, H.Y., GUO, L.J. \& LI, C.Y. 2004. Single-zircon U-Pb age of granodioritic gneiss in the Bayan Ul area, western Inner Mongolia. Regional Geology of China, 23, 1243-1245 (in Chinese with English abstract).

LI, Q.L., CHEN, F.K., GuO, J.H., LI, X.H., YANG, Y.H. \& SIEBEL, W. 2007. Zircon ages and Nd-Hf isotopic composition of the Zhaertai Group (Inner Mongolia): Evidence for early Proterozoic evolution of the northern North China Craton. Journal of Asian Earth Sciences, 30, 573-590.

LIU, D.Y., WAN, Y.S., WU, J.S., WILDE, S.A., ZHOU, H.Y., DONG, C.Y. \& YIN, X.Y. 2007. EoArchaean rocks and zircons in the North China Craton. In: (edited by) van Kranendonk, M.J., Smithies, R.H. \& Bennett, V.C., Developments in Precambrian Geology, 15 (in press).

LIU, J.Z., QIANG, X.K., LIU, X.S. \& OUYANG, Z.Y. 2000. Dynamics and genetic grids of sapphirine 
-bearing spinel gneiss in Daqing Mountain orogen zone, Inner Mongolia. Acta Petrologica Sinica, 16, 245-255 (in Chinese with English abstract).

LIU, S.W., LÜ Y.J., FENG, Y.G., ZHANG, C., TIAN, W. \& LIU, X.M. 2007. Geology and zircon U-Pb isotopic chronology of Dantazi Complex, Northern Hebei province. Geological Journal of China Universities, (in press) (in Chinese with English abstract).

LU, L.Z., XU, X.C. \& LIU, F.L. 1996. Early Precambrian Khondalite Series of North China. Changchun Publishing House, Changchun, 1-272 (in Chinese).

LUDWIG, K.R. 2001. Squid 1.02: A User's Manual, vol. 2. Berkeley Geochronology Centre, Special Publish, p. 19.

MOYEn, J.F., MARTIN, H., \& JAYANANDA, M., 2001. Multi-element geochemical modelling of crust-mantle interactions during late-Archaean crustal growth: the Closepet granite (South India). Precambrian Research, 112, 87-105.

Nutman, A.P., Dawes, P.R., KalsbeeK, F. \& Hamilton, M.A., 2007. Palaeoproterozoic and Archaean gneiss complexs in northern Greenland: Palaeoproterozoic tennane assembly in the High Arctic. Precambrian Research (in press). doi:10.1016/j.precamres.2007.09.006

QIAN, X.L. \& LI, J.H. 1999. The discovery of NeoArchaean unconformity and its implication for continental cratonization of the north China Craton. Sciences in China, Series. D, 42, 401-407.

Rogers, J.J.W. \& SANTOSH, M. 2002. Configuration of Columbia, a Mesoproterozoic supercontinent. Gondwana Research, 5, 5-22.

RoSEN, O.M., CONDIE, K.C., NATOPOV, L.M., 1994. Archaean and early proterozoic evolution of the Siberian Craton: a preliminary assessment. In: Condie, K.C. (Ed.), Archaean Crustal Evolution. Elsevier, pp. 411-459.

SANTOSH, M., SAJEeV, K. \& LI, J.H. 2006. Extreme crustal metamorphism during Columbia supercontinent assembly: Evidence from North China Craton. Gondwana Research, 10, 256-266.

SAntosh, M., TsunOGae, T., LI, J.H., LIU, S.J., 2007a. Discovery of sapphirine-bearing Mg-Al granulites in the North China Craton: implications for Palaeoproterozoic ultrahigh temperature metamorphism. Gondwana Research. 11, 263-285.

SANTOSH, M., WILDE, S.A., LI, J.H., 2007b. Timing of Palaeoproterozoic ultrahigh-temperature metamorphism in the North China Craton: Evidence from SHRIMP U-Pb zircon geochronology. Precambrian Research (in press). doi:10.1016/j.precamres.2007.06.006. 
SCHERER, E., MunKER, C. \& MEZGER, K. 2001. Calibration of the Lutetium-Hafnium clock: Science, 293, 683-687.

SHEN, Q.H., LIU, D.Y., WANG, P., GAO, J.F. \& ZHANG, Y.F. 1987. U-Pb and Rb-Sr isotopic age study of the Jining group from NEL Mongol of China. Bulletin of the Chinese Academy of Geological Sciences, 16, 165-178 (in Chinese with English abstract).

SHEN, Q.H., ZHANG, Y.F., GAO, J.F. \& WANG, P. 1990. Study on Archaean Metamorphic Rocks in Mid-southern Nei Mongol of China. Geological Publishing House, Beijing, p. 1-192 (in Chinese).

SONG, H.F., XU, Z.Y. \& LIU, Z.H. 2005. Geochemical characteristics and origin of garnet migmatitic granites in Daqingshan area, Inner Mongolia. Acta Petrologica et Mineralogica, 24, 489-495 (in Chinese with English abstract).

VAVRA, G., SCHMID, R. \& GEBAUER, D., 1999. Internal morphology, habit and U-Th-Pb microanalysis of amphibolite-to-granulite facies zircons: geochronology of the Ivrea Zone (Southern Alps). Contribution to Mineralogy and Petrology, 134, 380- 404.

WAN, Y.S., GENG, Y.S., LIU, F.L., SHEN, Q.H., LIU, D.Y. \& SONG, B., 2000a. Age and composition of the khondalites of the North China Craton and its adjacent area. Progress in Precambrian Research, 23, 221-235 (in Chinese with English abstract).

WAN, Y.S., GENG, Y.S., SHEN Q.H. \& ZHANG R.X., 2000b. Khondalite series-geochronology and geochemistry of the Jihekou Group in Luliang area, Shanxi Province. Acta Petrologica Sinica, 16, 49-58 (in Chinese with English abstract).

Wan, Y.S., SONG, B., LIU, D.Y., WILDE, S.A., WU, J.S., ShI, Y.R., YIN, X.Y. \& ZHOU, H.Y., 2006. SHRIMP U-Pb zircon geochronology of Palaeoproterozoic metasedimentary rocks in the North China Craton: evidence for a major Late Palaeoproterozoic tectonothermal event, Precambrian Research, 149, 249-271.

WAN, Y.S., LIU, D.Y., XU, Z.Y., DONG, C.Y., WANG, Z.J., WU, J.S., ZHOU, H.Y., YANG, Z.S. \& LIU, Z.H. 2007. Palaeoproterozoic crustally derived carbonatite from the Daqinshan area, North China Craton: Geological, petrographical, geochronological and geochemical (Hf, Nd, O and C) evidence. American Journal of Science, in review.

WANG, H.C. \& XIU, Q.Y. 1996. Single zircon U-Pb ages of Erdaowa group in Northern Hohhot, Inner Mongolia. Geology of Inner Mongolia, 1, 13-17 (in Chinese with English abstract).

WILDE, S.A., ZHAO, G.C., Sun, M., 2002. Development of the North China Craton during the Late 
Archaean and its final amalgamation at $1.8 \mathrm{Ga}$ : some speculation on its position within a global Palaeoproterozoic Supercontinent. Gondwana Research, 5, 85-94.

WANG, H.C., YUAN, G.B. \& XIN, H.T. 2001. U-Pb Single zircon ages for granulites in Cunkongshan area, Guyang Inner Mongolia and enlightenment for it's geological signification, China, Progress in Precambrian Research, 24, 28-34 (in Chinese with English abstract).

WILLIAMS, I.S. 1998. U-Th-Pb geochronology by ion microprobe, applications of microanalytical techniques to understanding mineralizing processes. In: MCKIBBEN, M.A., SHANKS, W.C. \& RIDLEY, W.I. (eds.). Reviews in Economic Geology, 7, 1-35.

WoOdheAD, J., Hergt, J., SHELley, M., EGGinS, S. \& KEMP, R. 2004. Zircon Hf-isotope analysis with an excimer laser, depth profiling, ablation of complex geometries, and concomitant age estimation. Chemical Geology, 209, 121-135.

WU, C.H. \& ZHONG, C.T. 1998. Early Proterozoic SW-NE collision model for the central part of the North China Craton. Progress in Precambrian Research, 21, 28-50 (in Chinese with English abstract).

WU, C.H., LI, H.M., ZHONG, C.T. \& CHEN, A.Q. 1998. The ages of zircon and rutile (cooling) from khondalite in Huangtuyao, Inner Mongolia. Geological Review, 44, 618-626 (in Chinese with English abstract).

Wu, C.H., ZHONG, C.T. \& ChEN, Q.G., 1997. Discussion on the age of khondalite in Jin-Meng (Shanxi-Nei Mongol) high-grade terrain. Acta Petrologica Sinica, 13, 289-302 (in Chinese).

WU, F.Y., YANG, Y.H., XIE, L.W., YANG, J.H. \& XU, P. 2006. Hf isotopic compositions of the standard zircons and baddeleyites used in U-Pb geochronology. Chemical Geology, 44, 105-126.

XIA, X.P., SUN, M., ZHAO, G.C. \& LUO, Y. 2006a. LA-ICP-MS U-Pb geochronology of detrital zircons from the Jining Complex, North China Craton and its tectonic significance. Precambrian Research, 144, 199-212.

Xia, X.P., Sun, M., ZhaO, G.C., WU, F.Y., Xu, P., Zhang, J.H. \& LuO, Y. 2006b. U-Pb and Hf isotopic study of detrital zircons from the Wulashan khondalites: Constraints on the evolution of the Ordos Terrane, Western Block of the North China Craton. Earth and Planetary Science Letters, 241, $581-593$.

XU, Z.Y., LIU, Z.H. \& YANG, Z.S. 2003. The discovery of Zaoergou angular unconformity and establishment of Meidaizhao Group-complex in Daqingshan Mountains, Inner Mongolia: 
Palaeoproterozoic low-grade metamorphic strata on the khondalite series. Geological Bulletin of China, 22, 480-486 (in Chinese with English abstract).

XU, Z.Y., LIU, Z.H., HU, F.X. \& YANG, Z.S. 2005. Geochemical characteristics of the calc-silicate rocks in khondalite series in Daqingshan area, Inner Mongolia. Journal of Jilin University (Earth Science Edition), 35, 681-689 (in Chinese with English abstract).

YANG, Z.S., XU, Z.Y. \& LIU, Z.H. 2000. Khondalite event and Archaean crust structure evolution. Progress in Precambrian Research, 23, 206-211 (in Chinese with English abstract).

YANG, Z.S., XU, Z.Y. \& LIU, Z.H., 2003, Consideration and practice of the construction of lithostratigraphic system in high-grade metamorphic terrains-A case study in the Daqingshan-Wulashan area: Geology in China, v. 30, p. 343-351 (in Chinese with English abstract).

YANG, Z.S., LIU, M.X., LIU, Z.H. \& XU, Z.Y., 2004. Explanatory text of the geological map of Baotou sheet, 1:250000. p. 1-572 (in Chinese).

YU, H.F., MEI, H.L., LI, Q., 1998. The characteristics of Archean khondalite series in Dunhuang, Gansu Province. Progress in Precambrian Research, 21, 19-25 (in Chinese with English abstract)

ZHANG, H.F., ZhAI, M.G. \& PENG, P. 2006. Zircon SHRIMP U-Pb age of the Palaeoproterozoic high-pressure granulites from the Sanggan area, the North China Craton and its geologic implications. Earth Science Frontiers, 13, 190-2199 (in Chinese with English abstract).

ZHANG, J.X., ZHANG, Z.M., XU, Z.Q., YANG, J.S. \& GUI, J.W. 2001. Petrology and geochronology of eclogites from the western segment of the Altyn Tagh, northwestern China. Lithos, 56, 187-206.

ZHAO, G.C., WILDE, S.A., CAWOOD, P.A. \& LU, L.Z., 1998. Thermal evolution of Archaean basement rocks from the eastern part of the North China craton and its bearing on tectonic setting. International Geology Review, 40, 705-721.

ZHAO, G.C., WILDE, S.A., CAWOOD, P.A. \& LU, L.Z., 1999. Tectonothermal history of the basement rocks in the western zone of the North China craton and its tectonic implications. Tectonophysics, 310, 37-53.

ZHAO, G.C., CAWOOD, P.A., WILDE, S.A., SuN, M. \& LU, L.Z. 2000. Metamorphism of basement rocks in the central zone of the north China craton: implications for Palaeoproterozoic tectonic evolution. Precambrian Research, 103, 55-88.

ZHAO, G.C., WILDE, S.A., CAWOOD, P.A. \& SUN, M., 2001. Archaean blocks and their boundaries in the North China Craton: lithological geochemical, structural and $P-T$ path constraints and tectonic 
evolution. Precambrian Research, 107, 45-73.

ZHAO, G.C., CAWOOD, P.A., WILDE, S.A. \& SUN, M. 2002. Review of global 2.1-1.8 Ga orogens: implications for a pre-Rodinia supercontinent. Earth-Science Reviews, 59, 125-162.

ZhAO, G.C., SUn, M., WILDE, S.A. \& LI, S.H., 2004. A Palaeo-Mesoproterozoic supercontinent: assembly, growth and breakup. Earth Science Reviews, 67, 91-123.

ZHAO, G.C., SUN, M., WILDE, S, A. \& LI, S.Z. 2005. Late Archaean to Palaeoproterozoic evolution of the North China Craton: key issues revisited. Precambrian Research, 136, 177-202.

ZHONG, C.T., DENG, J.F., WAN, Y.S., MAO, D.B., LI, H.M., CHEN, B. \& ZHOU, H.Y. 2006a. Zircon $\mathrm{U}-\mathrm{Pb} \mathrm{SHRIMP}$ dating and tectonic significations of adakite granite-sanukite-Closepet granite in Daqingshan of Inner Mongol, Beijing SHRIMP Centre annals (2005), Beijing Geological Publishing House, Beijing, p. 27-29 (in Chinese).

ZHONG, C.T., DENG, J.F., WAN, Y.S., MAO, D.B., XI, Z. \& CHEN, B. 2006b. Magma record of Palaeoproterozoic Orogen: Rock Geochemical characteristics and zircon SHRIMP dating of strongly peraluminous granitoids in the northern margin of the North China Craton, Beijing SHRIMP Centre annals (2005), Beijing Geological Publishing House, Beijing, p. 30-31 (in Chinese).

ZHOU, D.W., SU, L., JIAN, P., WANG, R.S., LIU, X.M., LU, G.X. \& WANG, J.L., 2004. Zircon U-Pb SHRIMP ages of high-pressure granulite in Yushugou ophiolitic terrane in southern Tianshan and their tectonic implications. Chinese Science Bulletin, 49, 1415-1419.

\section{Figure Captions}

Fig. 1. Geological map of the Daqingshan area, North China Craton (after Yang et al., 2004). Inset is simplified after Zhao et al. (2005). Also shown are sample locations in this study (triangles) and by Xia et al. (2006a) (circles).

Fig. 2. Field photographs of Precambrian rocks in the Daqingshan area, North China Craton.

(a) Two-pyroxene-bearing retrogressed granulite (NM0403) of the Sanggan "group", cut by meta-basic dyke (NM0404), northeast of Hademengou; (b) Felsic gneiss (NM0605) of the leucocratic gneiss unit of the lower Wulashan "group", north of Hademengou, showing anatectic features; (c) and (d) Meta-gabbro 
(NM0618), north of Hujigou; (c) shows evidence of partial melting,; (e) Garnet-biotite gneiss (NM0413) of the upper Wulashan "group", northwest of Maohudong, showing local melt structures; (f) garnet-biotite granite (NM0401) at Hademengou, showing banded structure,; (g) Garnet-biotite gneiss (NM0405) of the upper Wulashan "group", north of Maohudong; (h) Feldspathic quartzite (NM0414) of the Meidaizhao "group", $\sim 30 \mathrm{~km}$ southeast of Shiquai.

Fig. 3. Zircon cathodoluminescence images: (a), (b) and (c) Two-pyroxene-bearing retrogressed granulite (NM0403) from the Sanggan "group"; (d) meta-basic dyke (NM0404) which cuts the two-pyroxene-bearing retrogressed granulite (NM0403); (e) and (f) anatectic felsic gneiss (NM0605) from the lower Wulashan "group"; (g) and (h) meta-gabbro (NM0618). Ellipse $(\sim 30 \mu \mathrm{m})$ and circle $(\sim 60 \mu \mathrm{m})$ show positions of SHRIMP U-Pb and ICP-MS Hf analytical sites, respectively, with their identification numbers as in Tables EA-1 and 2. Py-pyroxene, Ap-apatite, Qz-quartz, Meta I- zircon formed during the first metamorphic event ( 2.5 Ga), Meta II-zircon formed during the second metamorphic event $(\sim 2.42$ $\mathrm{Ga})$.

Fig. 4. Concordia diagrams of SHRIMP U-Pb data: (a) Two-pyroxene-bearing retrogressed granulite (NM0403) from the Sanggan "group": black, magmatic core; grey,: Meta I; unfilled, Meta II; (b) meta-basic dyke (NM0404) cutting the two-pyroxene-bearing retrogressed granulite (NM0403); (c) anatectic felsic gneiss (NM0605) from the lower Wulashan "group": light grey, "core” of detrital zircon; unfilled, "rim" of detrital zircon; black, detrital zircon with banded texture; dark grey, metamorphic rim; (d) meta-gabbro (NM0618): unfilled, magmatic core; grey, metamorphic rim; (e) garnet-biotite gneiss (NM0413) from the upper Wulashan "group": grey, detrital core; unfilled, metamorphic rim; (f) garnet-biotite granite (NM0401) intruding the upper Wulashan "group": grey, inherited core; dark, metamorphic mantle; unfilled, magmatic rim; (g) garnet-biotite gneiss (NM0405) of the upper Wulashan "group": pale grey, detrital core; darker grey, metamorphic mantle; unfilled, metamorphic rim; black, outer metamorphic rim; (h) feldspathic quartzite (NM0414) of the Meidaizhao "group". Error ellipses are at the $1 \sigma$ level.

Fig. 5. Zircon cathodoluminescence images: (a) and (b) garnet-biotite gneiss (NM0413) from the upper Wulashan "group"; (c) and (d) garnet-biotite granite (NM0401) intruding the upper Wulashan "group"; (e), 
(f) and (g) garnet-biotite gneiss (NM0405) of the upper Wulashan "group"; curve in (g) represents the boundary of the outer rim of the zircon grain which has been partly destroyed during polishing; (h) feldspathic quartzite (NM0414) of the Meidaizhao "group". Ellipse $(\sim 30 \mu \mathrm{m})$ and circle $(\sim 60 \mu \mathrm{m})$ show position of SHRIMP U-Pb and ICP-MS Hf analytical sites, respectively, with their identification numbers as in Tables EA-1 and 2.

Fig. 6. $\varepsilon_{\mathrm{Hf}}(t)$ vs. ${ }^{207} \mathrm{~Pb} /{ }^{206} \mathrm{~Pb}$ age diagram of zircons from Precambrian rocks in the Daqingshan area

Fig. 7. Age histogram of Precambrian zircons from the "extended" Khondalite Belt, North China Craton Data sources are from Table 2. 1) Dating methods include TIMS isotope dilution, TIMS evaporation, SHRIMP and LAM-ICPMS; 2) the data-set of seventy-seven zircons include both ${ }^{207} \mathrm{~Pb} /{ }^{206} \mathrm{~Pb}$ weighted mean and upper intercept ages; the latter are marked with an asterisk in Table 2; 3) the bin width is $25 \mathrm{Ma}$. 4) Age distribution of magmatic, metamorphic and detrital (plus inherited) zircons is shown separately. 


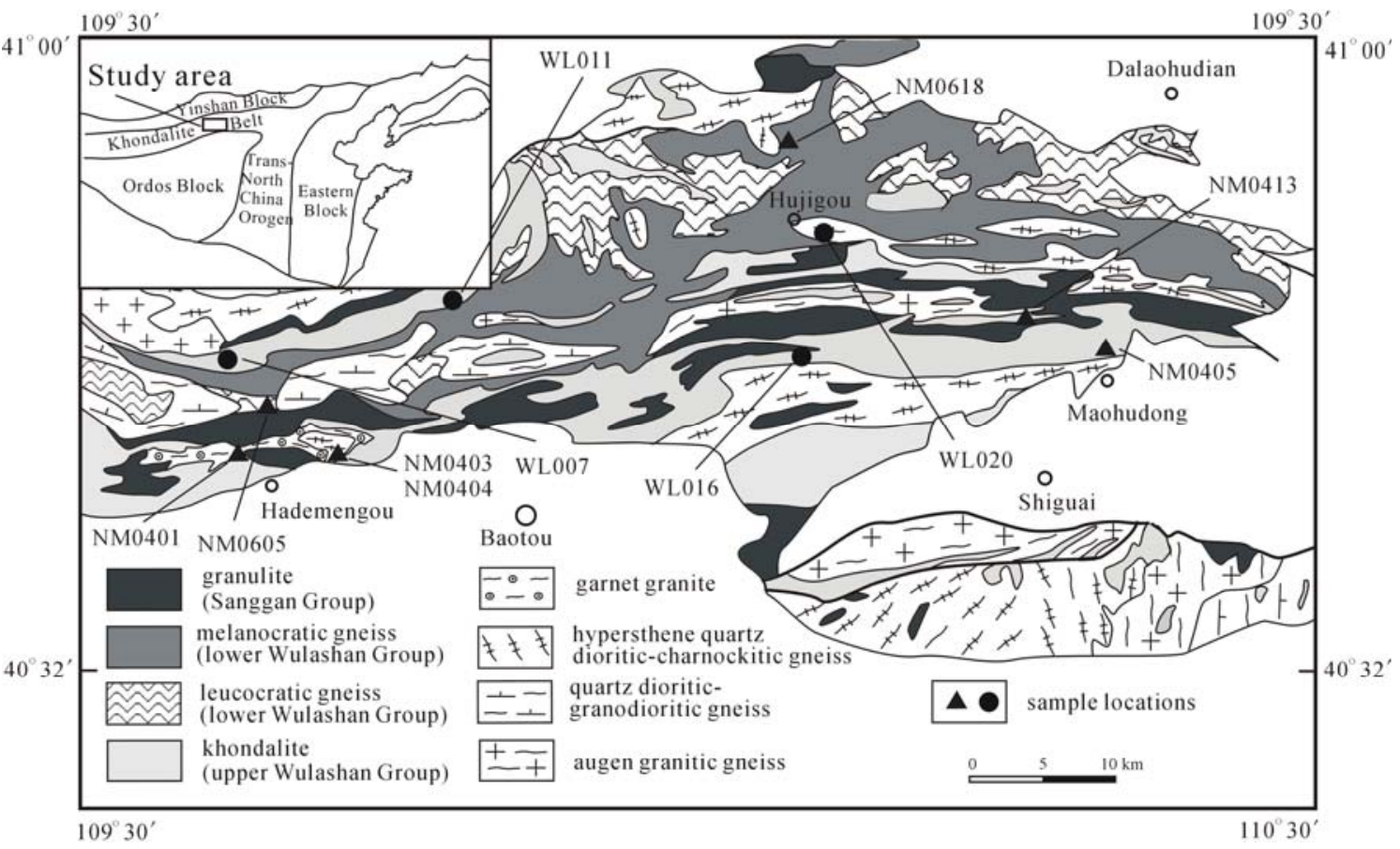

Fig.1 

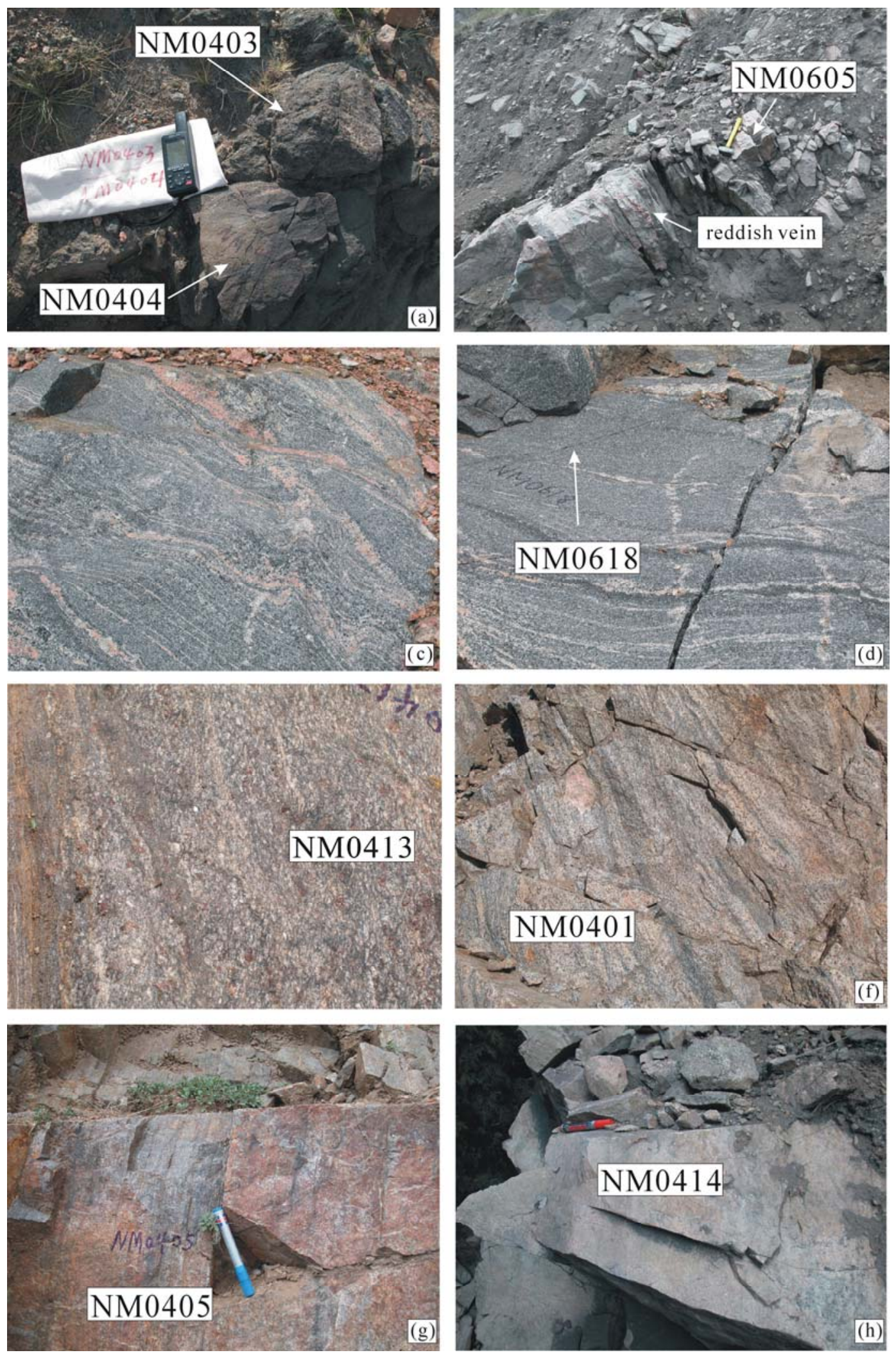

Fig.2 

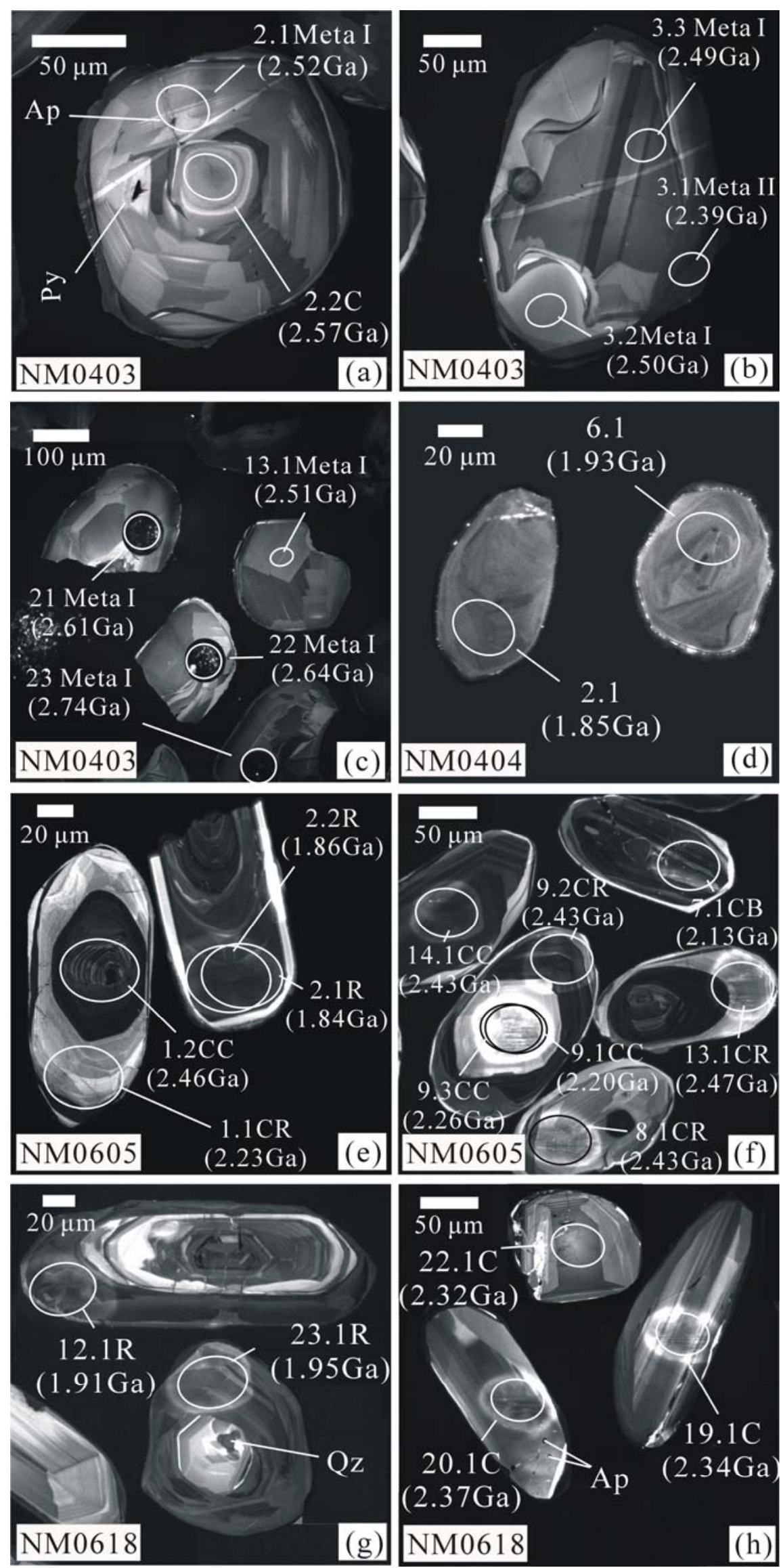

Fig.3 

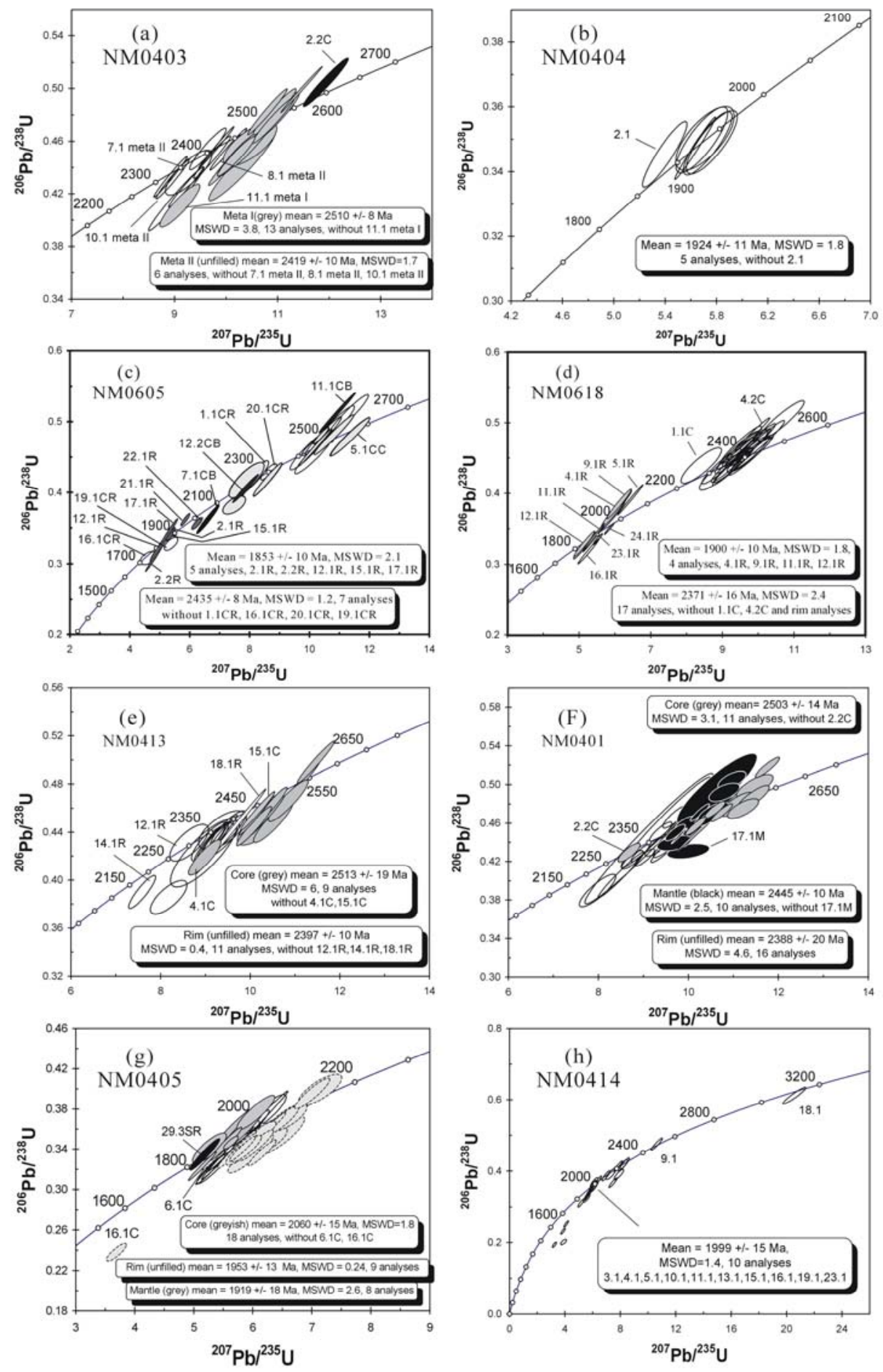

Fig.4 

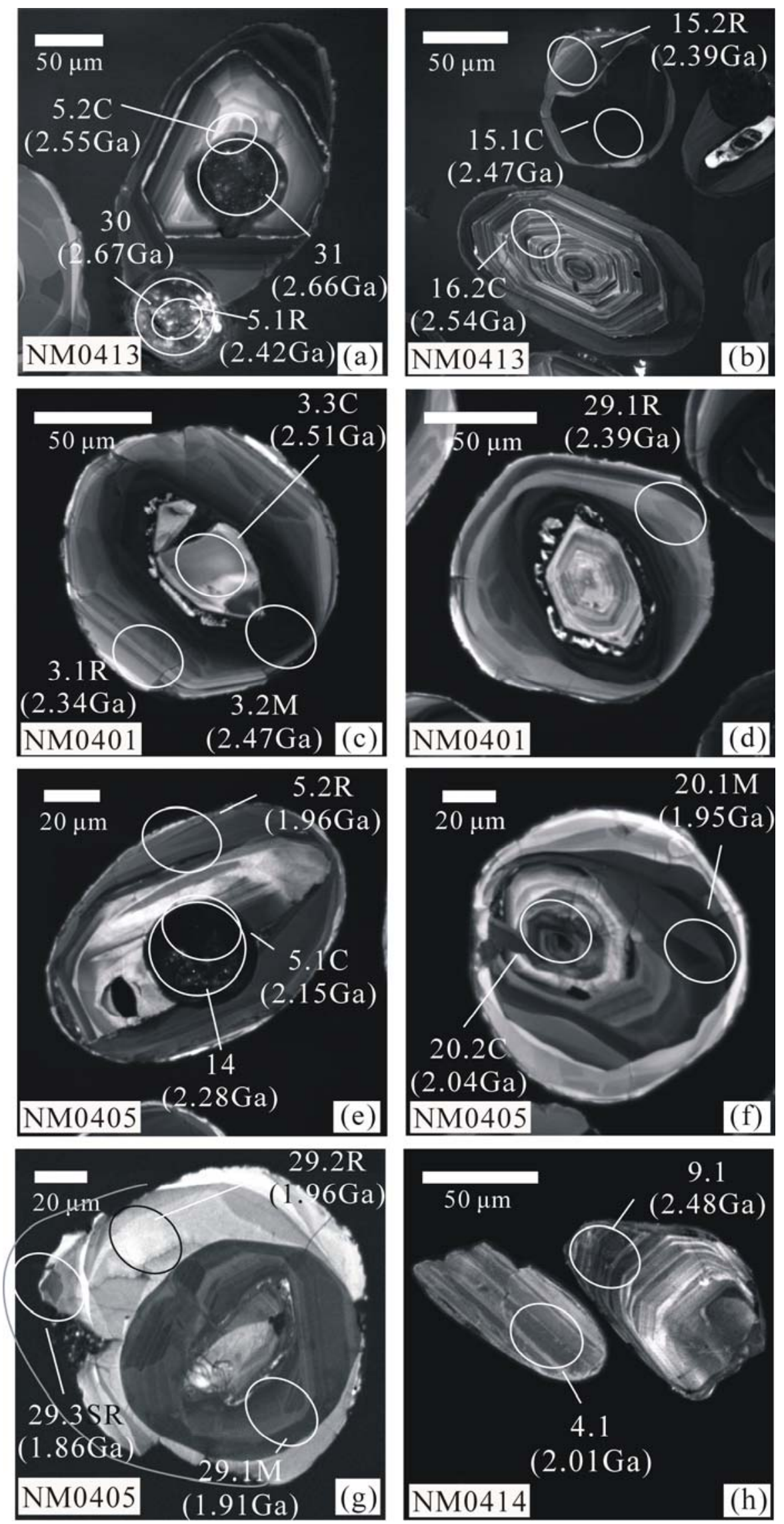

Fig.5 


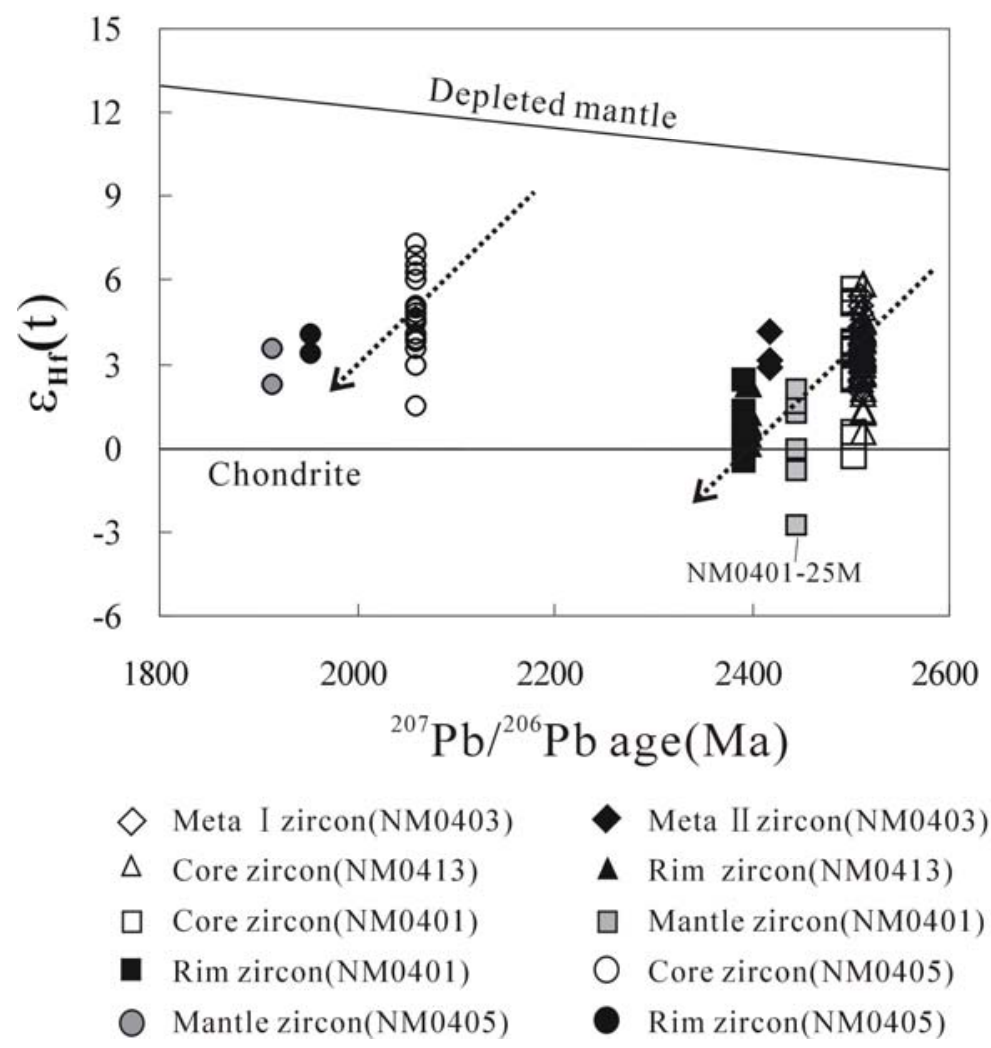

Fig.6 


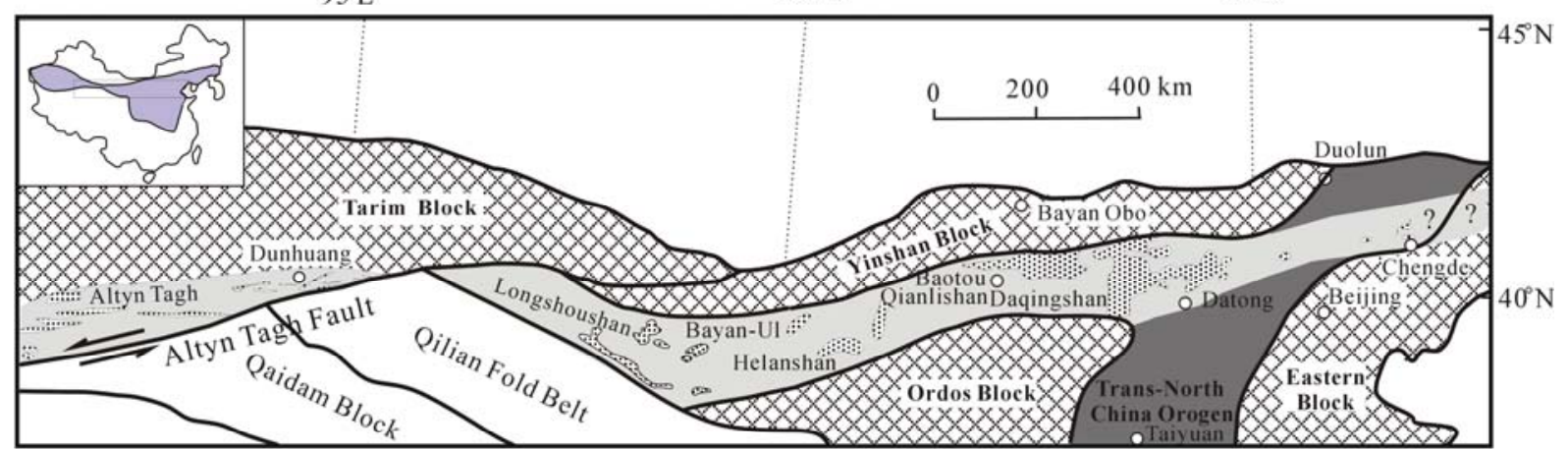

$\mathbb{X}$ Archaean basement

Fig.7 


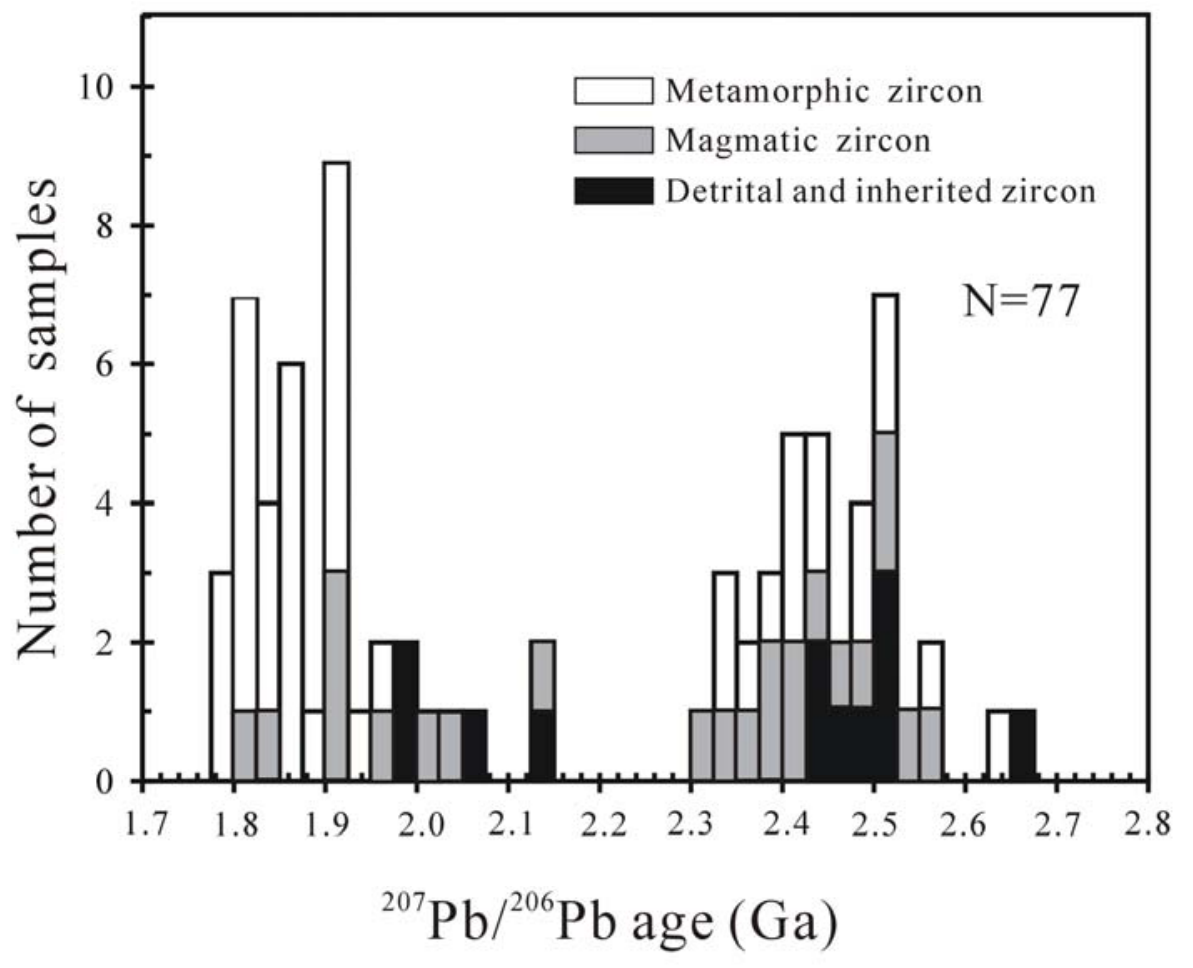

Fig.8 